\title{
GLP-1 stimulates insulin secretion by PKC-dependent TRPM4 and TRPM5 activation
}

\author{
Makoto Shigeto, ${ }^{1,2,3}$ Reshma Ramracheya, ${ }^{1}$ Andrei I. Tarasov, ${ }^{1,4}$ Chae Young Cha, ${ }^{1,2}$ Margarita V. Chibalina, ${ }^{1}$ Benoit Hastoy, ${ }^{1}$ \\ Koenraad Philippaert, ${ }^{5}$ Thomas Reinbothe, ${ }^{2}$ Nils Rorsman, ${ }^{1,6}$ Albert Salehi, ${ }^{2}$ William R. Sones, ${ }^{1}$ Elisa Vergari, ${ }^{1}$ Cathryn Weston, \\ Julia Gorelik, ${ }^{8}$ Masashi Katsura, ${ }^{3}$ Viacheslav O. Nikolaev, ${ }^{9}$ Rudi Vennekens, ${ }^{5}$ Manuela Zaccolo, ${ }^{10}$ Antony Galione, ${ }^{6}$ \\ Paul R.V. Johnson, ${ }^{1,4}$ Kohei Kaku, ${ }^{3}$ Graham Ladds, ${ }^{7,11}$ and Patrik Rorsman ${ }^{1,2,4}$ \\ ${ }^{1}$ Oxford Centre for Diabetes, Endocrinology and Metabolism, Churchill Hospital, Oxford, United Kingdom. Institute of Neuroscience and Physiology, Department of Physiology, Metabolic Research Unit, \\ University of Gothenborg, Gothenborg, Sweden. ${ }^{3}$ Department of Diabetes, Endocrinology and Metabolism, Kawasaki Medical School, Kurashiki, Okayama, Japan. ${ }^{4}$ Oxford National Institute for Health \\ Research, Biomedical Research Centre, Churchill Hospital, Oxford, United Kingdom. ${ }^{5}$ Laboratory of lon Channel Research, Department of Cellular and Molecular Medicine, Katholieke Universiteit Leuven, \\ Leuven, Belgium. 'Department of Pharmacology, University of Oxford, Oxford, United Kingdom. ’Division of Biomedical Cell Biology, Warwick Medical School, University of Warwick, Coventry, United King- \\ dom. ${ }^{8}$ Department of Cardiovascular Sciences, National Heart and Lung Institute, Imperial College London, London, United Kingdom. ${ }^{9}$ Institute of Experimental Cardiovascular Research, Universitätsklini- \\ kum Hamburg-Eppendorf, Hamburg, Cermany. ${ }^{10}$ Department of Physiology, Anatomy and Genetics, University of Oxford, Oxford, United Kingdom. "Department of Pharmacology, University of Cambridge, \\ Cambridge, United Kingdom.
}

\begin{abstract}
Strategies aimed at mimicking or enhancing the action of the incretin hormone glucagon-like peptide 1 (GLP-1) therapeutically improve glucose-stimulated insulin secretion (CSIS); however, it is not clear whether CLP-1 directly drives insulin secretion in pancreatic islets. Here, we examined the mechanisms by which GLP-1 stimulates insulin secretion in mouse and human islets. We found that GLP-1 enhances CSIS at a half-maximal effective concentration of $0.4 \mathrm{pM}$. Moreover, we determined that GLP-1 activates PLC, which increases submembrane diacylglycerol and thereby activates PKC, resulting in membrane depolarization and increased action potential firing and subsequent stimulation of insulin secretion. The depolarizing effect of CLP-1 on electrical activity was mimicked by the PKC activator PMA, occurred without activation of PKA, and persisted in the presence of PKA inhibitors, the $\mathrm{K}_{\text {ATP }}$ channel blocker tolbutamide, and the L-type $\mathrm{Ca}^{2+}$ channel blocker isradipine; however, depolarization was abolished by lowering extracellular $\mathrm{Na}^{+}$. The PKC-dependent effect of GLP-1 on membrane potential and electrical activity was mediated by activation of $\mathrm{Na}^{+}$-permeable TRPM4 and TRPM5 channels by mobilization of intracellular $\mathrm{Ca}^{2+}$ from thapsigargin-sensitive $\mathrm{Ca}^{2+}$ stores. Concordantly, GLP-1 effects were negligible in Trpm4 or Trpm5 KO islets. These data provide important insight into the therapeutic action of CLP-1 and suggest that circulating levels of this hormone directly stimulate insulin secretion by $\beta$ cells.
\end{abstract}

\section{Introduction}

Type 2 diabetes currently affects approximately 350 million individuals in the world (1). It is caused by insufficient insulin secretion, often in combination with impaired insulin action (2). The reduced insulin secretion has been attributed to impaired $\beta$ cell function, $\beta$ cell mass, or a combination of the two (2).

Therapies based on the incretin hormone glucagon-like peptide 1 (GLP-1) have been introduced during the last 10 years. They include long-lasting GLP-1 analogs and inhibitors of dipeptidyl peptidase 4 (DPP-4), the enzyme degrading the active form of GLP-1 [GLP-1(7-36) amide] to its less active metabolite [GLP-1(9-36) amide]. Their actions culminate in e glucose-dependent stimulation of insulin secretion from the pancreatic $\beta$ cells $(3,4)$.

The plasma concentration of biologically active GLP-1 [GLP-1(7-36) amide] is in the picomolar range and does not increase

\section{Related Commentary: p. 4327}

Conflict of interest: The authors have declared that no conflict of interest exists. Submitted: April 13, 2015; Accepted: October 1, 2015

Reference information: / Clin Invest. 2015;125(12):4714-4728. doi:10.1172/JCI81975. beyond $\sim 20 \mathrm{pM}$, even after a meal $(5,6)$. Moreover, administration of DPP-4 inhibitors increases the peripheral blood concentration of GLP-1 by only a few picomolars and yet results in marked stimulation of insulin secretion and a fall in plasma glucose levels (5, 6). Effects of physiological levels of GLP-1 in neurons (7), skeletal muscle cells $(8)$, hepatocytes $(9)$, and adipocytes $(10,11)$ have been reported. Nevertheless, most in vitro studies of the effects GLP-1 on pancreatic islet function use nanomolar $(1-100 \mathrm{nM})$ concentrations of GLP-1 (12-15), i.e., levels >100- to 10,000-fold higher than those occurring physiologically. The use of such high concentrations is predicated on receptor-binding assays and measurements of intracellular cAMP accumulation, which suggest a half-maximal effective concentration $\left(\mathrm{EC}_{50}\right)$ of approximately $5 \mathrm{nM}(16-18)$. Because of the huge discrepancy between the plasma GLP-1(7-36) levels and those assumed required to stimulate insulin secretion in isolated pancreatic islets, it has been proposed that GLP-1 released from the intestinal $L$ cells acts by activation of vago-vagal reflexes that culminate in neurally mediated stimulation of insulin secretion (19).

The GLP-1 receptor (GLP-1R) is coupled to the GTP-binding protein $G_{a s}$, which activates adenyl cyclase, and many of the effects of GLP-1 are mediated by an increase in the intracellular 

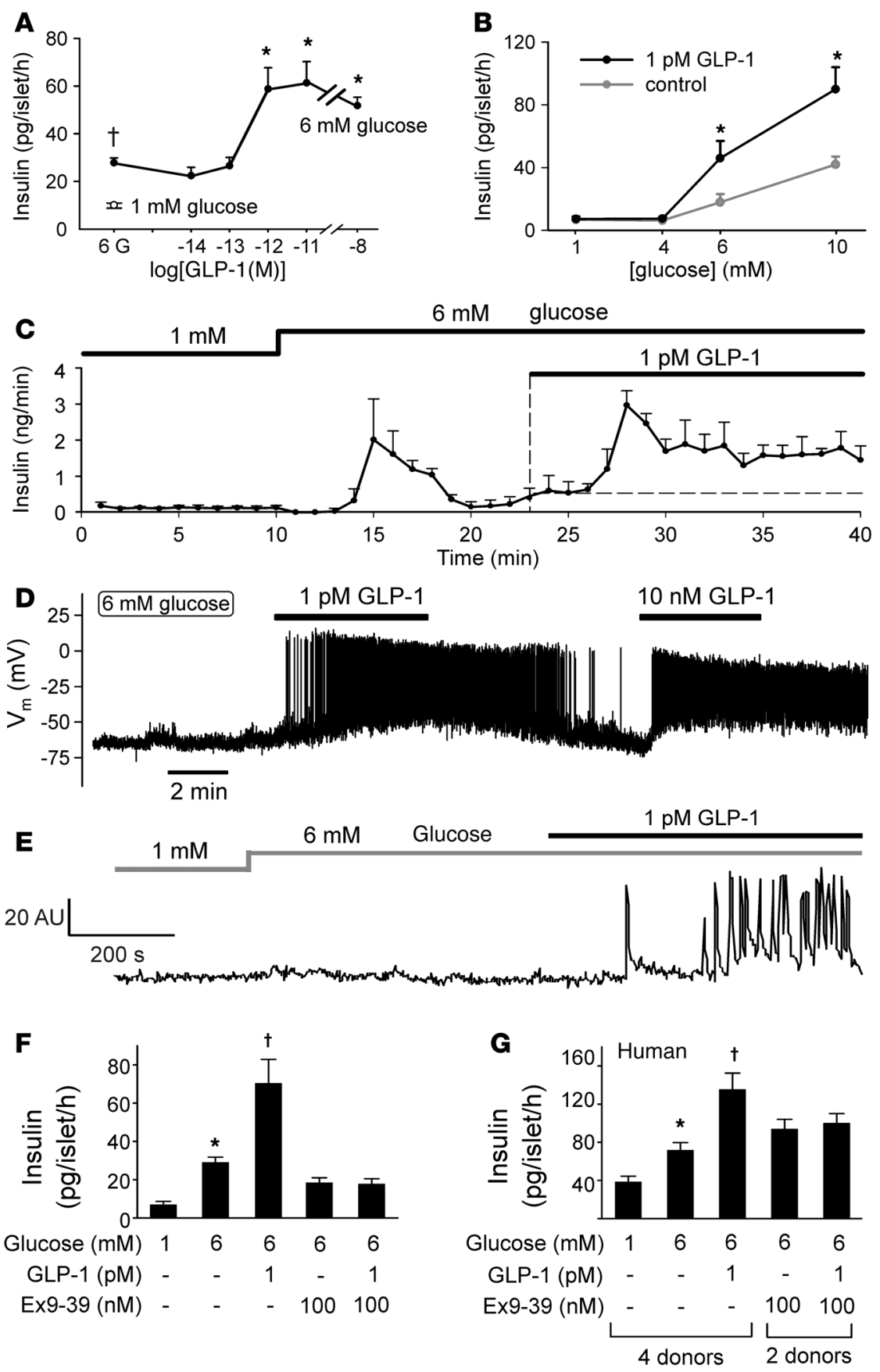

Figure 1. Stimulatory effects of picomolar concentrations of CLP-1 on insulin secretion, electrical activity, and $\left[\mathrm{Ca}^{2+}\right]_{\mathrm{i}^{*}}$ (A) Insulin secretion measured at $6 \mathrm{mM}$ glucose (black circle) and increasing concentrations of GLP-1 ( $n=4-8$ experiments). The white circle shows insulin secretion measured at $1 \mathrm{mM}$ glucose in the absence of GLP-1. ${ }^{+} \mathrm{P}<0.05$ vs. $1 \mathrm{mM}$ glucose, ${ }^{*} P<0.05$ vs. $6 \mathrm{mM}$ glucose (1-way ANOVA with Dunnett's post-hoc test). (B) Insulin secretion at 1, 4, 6, and $10 \mathrm{mM}$ glucose in the absence and presence of 1 pM GLP-1 $(n=9$ experiments). ${ }^{*} P<0.01$ vs. no GLP-1 (Student's $t$ test). (C) GLP-1 (1 pM) stimulated insulin secretion from perfused mouse pancreas $(n=4)$. (D) Membrane potential recording from a $\beta$ cell exposed sequentially to $1 \mathrm{pM}$ and $10 \mathrm{nM}$ GLP-1 (representative of 24 of 25 cells). (E) Spontaneous [ $\left.\mathrm{Ca}^{2+}\right]_{i}$ oscillations in a $\beta$ cell within an intact islet exposed to $1 \mathrm{pM}$ GLP-1 (representative of 23 of 35 cells in 3 islets from 3 mice). (F) Insulin secretion in mouse islets at $6 \mathrm{mM}$ glucose in the absence and presence of 1 pM GLP-1 and/or $100 \mathrm{nM}$ exendin (9-39) (Ex9-39). ${ }^{*} P<0.05$ vs. $1 \mathrm{mM}$ glucose, ${ }^{\dagger} P<0.05$ vs. $6 \mathrm{mM}$ glucose ( $n=3-5$; 1-way ANOVA with Dunnett's post-hoc test). (G) As in $\mathbf{F}$ but using human islets ( $n=8-12$ with islets from 2-4 donors). ${ }^{*} P<0.05$ vs. $1 \mathrm{mM}$ glucose, ${ }^{\dagger} P<<0.05$ vs. $6 \mathrm{mM}$ glucose ( $n=3-5$; 1-way ANOVA with Dunnett's post-hoc test).

\section{Results}

Picomolar concentrations of GLP-1 stimulate insulin secretion, electrical activity, and $\left[\mathrm{Ca}^{2+}\right]_{i}$ oscillations. In mouse islets, GLP-1 potentiated glucose-induced insulin secretion in a dosedependent manner at between $0.1 \mathrm{pM}$ and 10 $\mathrm{pM}$, with a calculated $\mathrm{EC}_{50}$ of approximately $0.4 \mathrm{pM}$ (Figure 1A). Thus, the stimulatory effect of 1 pM GLP-1 was maximal and as strong as that observed at $10 \mathrm{nM}$, which (if anything) produced less stimulation than a 1,000- to 10,000-fold lower concentration.

We determined the glucose dependence of the stimulatory effect of $1 \mathrm{pM}$ GLP-1 (Figure 1B). Whereas GLP-1 was without effect at 1 and $4 \mathrm{mM}$ glucose, insulin secretion at 6 and 10 $\mathrm{mM}$ was strongly potentiated. Thus, the stimulatory effect of picomolar levels of GLP-1 is only cAMP levels. However, coupling to the GTP-binding proteins $\mathrm{G} \alpha_{\mathrm{i} / \mathrm{o}}$ and $G \alpha_{q / 11}$ has also been reported (20-23), but the downstream functional consequences remain largely unexplored.

Here, we have determined the concentration dependence of the stimulatory effect of GLP-1 on glucose-stimulated insulin secretion in intact mouse and human pancreatic islets. We demonstrate that GLP-1 stimulates insulin secretion with an $\mathrm{EC}_{50}$ of approximately $0.4 \mathrm{pM}$ and that a concentration of $1 \mathrm{pM}$ is at least as stimulatory as $10 \mathrm{nM}$. This effect involves activation of the GLP-1R and is PKC-dependent and mediated by membrane depolarization due to activation of $\mathrm{Na}^{+}$-permeable TRPM4 and TRPM5 channels, culminating in increased action potential firing rates and $\mathrm{Ca}^{2+}$ dependent stimulation of insulin exocytosis.
We confirmed the stimulatory capacity physiological concentrations of GLP-1 using the perfused pancreas preparation, whereby GLP-1 is delivered by the vascular system (Figure 1C). Increasing glucose from 1 to $6 \mathrm{mM}$ evoked a biphasic stimulation of insulin secretion and transiently increased it from a basal rate of $0.1 \mathrm{ng} / \mathrm{min}$ to a peak value of approximately $2 \mathrm{ng} /$ min, after which the secretory rate fell to approximately 0.5 $\mathrm{ng} / \mathrm{min}$. Subsequent administration of $1 \mathrm{pM}$ GLP-1 produced a marked biphasic stimulation of insulin secretion, in excess of that evoked by $6 \mathrm{mM}$ glucose alone, to a new peak value of 3 $\mathrm{ng} / \mathrm{min}$, before declining to a new plateau of of approximately $1.5 \mathrm{ng} / \mathrm{min}$. observed at glucose concentrations that are themselves stimulatory. 
A
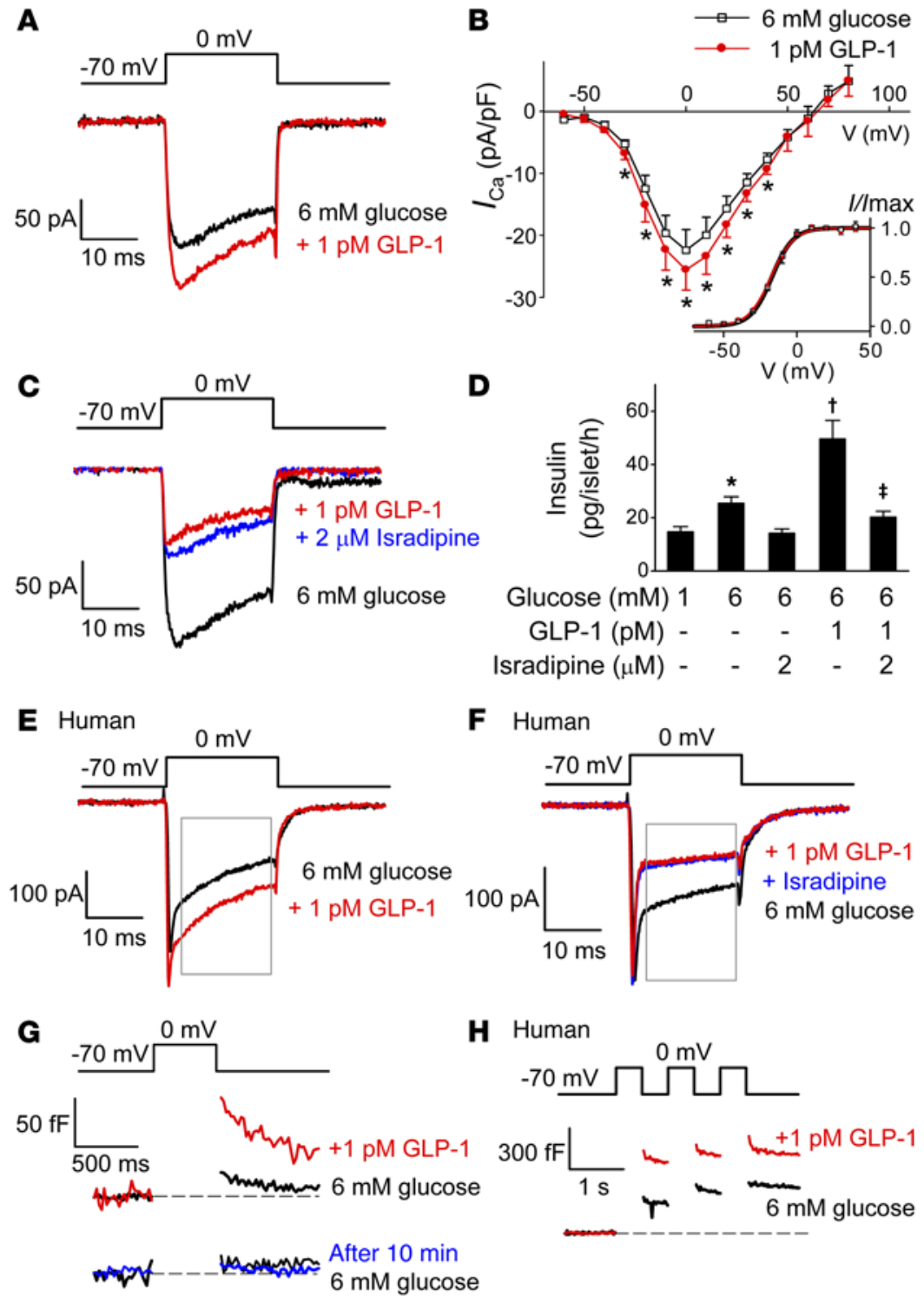

Figure 2. Stimulatory effects of low concentrations of GLP-1 depend on L-type $\mathrm{Ca}^{2+}$ channels. (A) GLP-1

$(1 \mathrm{pM})$ enhances mouse $\beta$ cell Ca ${ }^{2+}$ currents $\left(I_{\mathrm{Ca}}\right)$ evoked by 20 - $\mathrm{ms}$ depolarization from $-70 \mathrm{mV}$ to $0 \mathrm{mV}(n=7$ cells from 5 mice). (B) Current-voltage (I-V) relationships of whole-cell $\mathrm{Ca}^{2+}$ currents in the absence (black) and presence (red) of GLP-1. Current amplitudes have been normalized to cell capacitance. $\mathrm{Ca}^{2+}$ current activation curves are shown in the inset in the absence and presence of GLP-1. ${ }^{*} P<0.05$ vs. control by paired Student's $t$ test ( $n=5$ cells from 3 mice). (C) GLP- 1 inhibits $I_{\text {Ca }}$ when added in the presence of isradipine (added 5 minutes prior to the addition of GLP-1) ( $n=5$ cells from 3 mice). (D) Effects of GLP-1 on insulin secretion in mouse islets in the absence and presence of GLP-1 and/or isradipine. Isradipine was included during the 30-minute preincubation. ${ }^{*} P<0.05$ vs. 1 mM glucose; ${ }^{\dagger} P<0.05$ vs. $6 \mathrm{mM}$ glucose; ${ }^{\ddagger} P<0.01$ vs. $6 \mathrm{mM}$ glucose plus GLP-1 ( $n=7-8$; 1-way ANOVA with Dunnett's posthoc test). (E and $\mathbf{F}$ ) As in $\mathbf{A}$ and $\mathbf{C}$ but using human $\beta$ cells ( $n=13$ cells from 6 donors in $\mathbf{E} ; n=6$ cells from 3 donors in F). Rectangles indicate the period used for measuring charge entry $\left(\underline{O}_{\mathrm{Ca}}\right)$ to avoid contribution of voltage-gated $\mathrm{Na}^{+}$current (initial spiky component).

(C) Exocytosis measured as an increase in membrane capacitance evoked by 500-ms depolarizations from $-70 \mathrm{mV}$ to $0 \mathrm{mV}$ under control conditions (6 $\mathrm{mM}$ glucose, black) and 10 minutes after addition of GLP-1 (red). A control experiment showing that when GLP-1 was not added, the exocytotic responses remained small and stable for 10 minutes (blue; $n=5$ ), is also shown. (H) Exocytosis elicited by a train of three 500 $\mathrm{ms}$ depolarizations from $-70 \mathrm{mV}$ to $0 \mathrm{mV}$ in a human $\beta$ cell before (black) and 10 minutes after (red) the addition of GLP-1 (representative of 5 cells from 3 donors).

approximately $5 \%$ of the cells (similar to the fraction of cells generating spontaneous action potentials). However, GLP-1 (consistent with data of Figure 1D and previous reports, see ref. 24) resulted in substantial recruitment of cells, and in the simultaneous presence of $1 \mathrm{pM}$ GLP-1 and $6 \mathrm{mM}$ glucose, $65 \%$ of cells showed $\left[\mathrm{Ca}^{2+}\right]_{\mathrm{i}}$

Insulin secretion is secondary to $\beta$ cell electrical activity. We therefore correlated the stimulation of insulin secretion by low and high concentrations of GLP-1 to the effects on electrical activity (Figure 1D). In single $\beta$ cells exposed to $6 \mathrm{mM}$ glucose alone, the membrane potential averaged $-66 \pm 7 \mathrm{mV}(n=36)$, but only a fraction of these cells $(10 \%, 4$ of 40 cells) generated spontaneous action potentials, and then only transiently upon addition of glucose, echoing the transient stimulation of insulin secretion. However, upon application of $1 \mathrm{pM}$ GLP-1, action potential firing was initiated in almost every cell ( 24 of 25 cells). At steady state, the rate of action potential firing in $\beta$ cells exposed to $6 \mathrm{mM}$ glucose averaged $0.003 \pm 0.003 \mathrm{~Hz}$, which increased to $3.4 \pm 0.3 \mathrm{~Hz}$ $(n=24)$ after addition of $1 \mathrm{pM}$ GLP-1. The response to $1 \mathrm{pM}$ GLP-1 was at least as strong as that evoked by a 10,000-fold higher concentration of the incretin hormone (Figure 1D).

The effects of GLP-1 on electrical activity correlated with the induction of $\left[\mathrm{Ca}^{2+}\right]_{\mathrm{i}}$ oscillations in a subset of cells within intact mouse pancreatic islets (Figure 1E). At $6 \mathrm{mM}$ glucose alone, spontaneous $\left[\mathrm{Ca}^{2+}\right]_{i}$ oscillations were seen in only oscillations. A similar increase in the fraction of cells exhibiting $\left[\mathrm{Ca}^{2+}\right]_{\mathrm{i}}$ oscillations was observed when glucose was elevated from 6 to $20 \mathrm{mM}(25)$.

We finally confirmed that the effects of 1 pM GLP-1 on glucose-induced insulin secretion can be blocked by the GLP-1R antagonist exendin (9-39). In this series of experiments, GLP-1 potentiated insulin secretion at $6 \mathrm{mM}$ glucose 2.5 -fold, an effect that was completely reversed by exendin (9-39) (Figure 1F). In addition, picomolar concentrations of GLP-1 stimulated insulin secretion in human islets, an effect that was likewise antagonized by exendin (9-39) (Figure 1G). These observations suggest that the effects of picomolar levels of GLP-1 in both mouse and human $\beta$ cells are mediated by the previously characterized GLP-1R (17).

Picomolar concentrations of GLP-1 stimulate L-type $\mathrm{Ca}^{2+}$ channel activity and $\beta$ cell exocytosis. In single mouse $\beta$ cells exposed to 6 $\mathrm{mM}$ glucose, addition of $1 \mathrm{pM}$ GLP-1 increased the integrated $\mathrm{Ca}^{2+}$ current $\left(Q_{\mathrm{Ca}}\right)$ evoked by a 20 -ms voltage-clamp pulse from -70 $\mathrm{mV}$ to $0 \mathrm{mV}$ by approximately $15 \%$, from $-2.6 \pm 0.47 \mathrm{pC}$ to $-3.2 \pm$ $0.59 \mathrm{pC}(P<0.01$ by paired Student's $t$ test; Figure $2 \mathrm{~A})$. In previous 
A

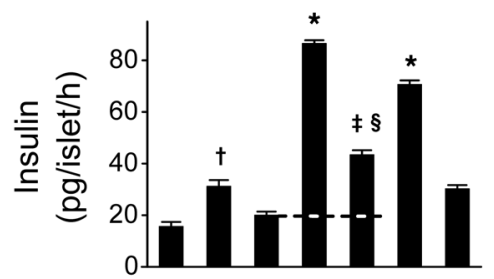

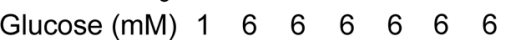

GLP-1 (pM) - $\quad-\quad \begin{array}{llllllllll} & 1 & 1 & - & -\end{array}$

myr-PKI $(\mu \mathrm{M})-\quad-1-1 \quad 1$

Forskolin $(\mu \mathrm{M})$ - $\quad-\quad-\quad-\quad 2 \quad 2$

C
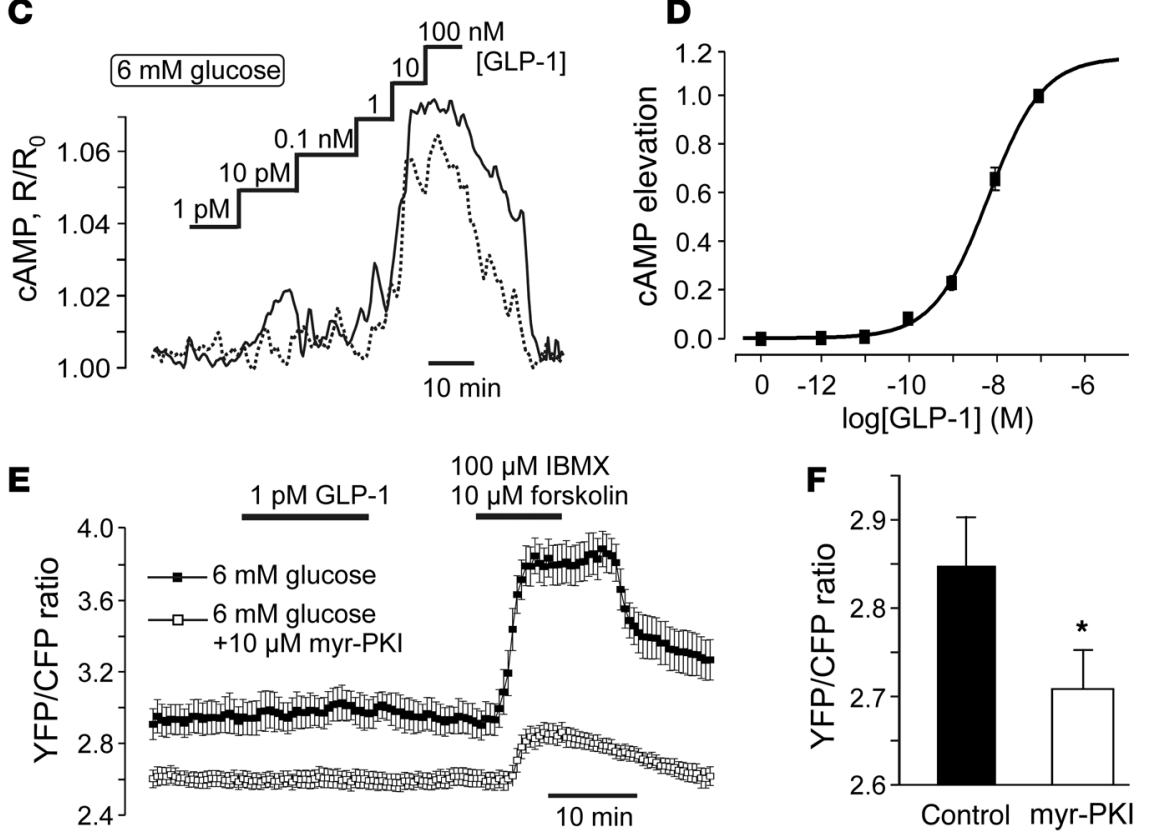

Figure 3. PKA-independent effects of GLP-1. (A) Effects of glucose and 1 pM GLP-1 on insulin secretion in mouse islets in the absence and presence of the membrane-permeable PKA inhibitor myr-PKI $(1 \mu \mathrm{M}$; introduced during 30 -minute preincubation). ${ }^{\dagger} P<0.05$ vs. 1 mM glucose; ${ }^{*} P<0.01$ vs. 6 mM glucose; ${ }^{\ddagger} P<0.01$ vs. 6 mM glucose plus $1 \mathrm{pM}$ CLP-1; $\$ P<0.01$ vs. 6 mM glucose and $1 \mu$ M myr-PKI ( $n=8$ experiments; 1-way ANOVA with Dunnett's post-hoc test). (B) As in A but using human islets ( $n=6-7$ from 3 donors, not the same as in Figure 1C) and using Rp-8-Br-cAMPS to inhibit PKA. (C) Changes in [CAMP], concentration in response to increasing concentrations of GLP-1 (indicated above the traces) measured using recombinant cAMP sensor Epac2-camps in 2 representative cells (continuous and dotted lines). The CFP/YFP ratio $R$ has been normalized to its initial value $R_{0}$. (D) Relationship between GLP-1 concentration and elevation of [cAMP] $]_{i}(n=33$ cells from 4 mice). The dose-response curve was fit to a Hill equation (Equation 2). (E) PKA activity measured in single cells from PKI-pretreated ( $n=22$, white squares) and control ( $n=24$, black squares) cells. GLP-1, 3-isobutyl-1-methylxanthine (IBMX) and forskolin were added as indicated. (F) Basal YFP/CFP ratio in control $(n=67)$ and PKI-pretreated $(n=65,1$ hour, $10 \mu \mathrm{M}$ ) islet cells. ${ }^{*} P<0.05$ (Mann-Whitney nonpaired test).

In human $\beta$ cells, GLP-1 increased the L-type $\mathrm{Ca}^{2+}$ current from $-3.0 \pm 0.6 \mathrm{pC}$ to $-3.4 \pm$ $0.8 \mathrm{pC}(P<0.05$, paired Student's $t$ test; Figure 2E). Application of isradipine inhibited $Q_{\mathrm{Ca}}$ by $48 \% \pm 9 \%(P<0.05)$, and GLP-1 had no effect in the presence of the blocker (Figure 2F).

Insulin granule exocytosis evoked by experiments using $10 \mathrm{nM} \mathrm{GLP-1}$, no effect on $Q_{\mathrm{Ca}}$ was detected (26), a finding we confirmed (data not shown).

Figure 2B shows the peak $\mathrm{Ca}^{2+}$ current-voltage relationships recorded under control conditions and in the presence of 1 pM GLP-1. GLP-1 increased the peak $\mathrm{Ca}^{2+}$ currents during pulses to membrane potentials of between $-20 \mathrm{mV}$ and $+20 \mathrm{mV}$ by $10 \%$ to $15 \%$. We examined whether the increased peak $\mathrm{Ca}^{2+}$ current amplitude was associated with a shift in the voltage dependence of the gating. However, no differences in the activation parameters were observed between control conditions, which, following addition of GLP-1 and $V_{\mathrm{h}}$ (the membrane potential at which activation is half-maximal; see Methods and Equation 1), averaged $-17 \pm 1 \mathrm{mV}$ and $-17 \pm 2 \mathrm{mV}$ in the absence and presence of 1 pM GLP-1, respectively.

The increase in $Q_{\mathrm{Ca}}$ produced by 1 pM GLP-1 reflects activation of L-type $\mathrm{Ca}^{2+}$ channels (Figure 2C). The L-type $\mathrm{Ca}^{2+}$ channel blocker isradipine reduced $Q_{\mathrm{Ca}}$ from $-2.6 \pm 0.70 \mathrm{pC}$ to $-0.68 \pm 0.09 \mathrm{pC}(P<0.01$ by paired Student's $t$ test). When 1 pM GLP-1 was added in the presence of isradipine, it decreased $Q_{\mathrm{Ca}}$ to $-0.59 \pm 0.09 \mathrm{pC}(P<0.05$ vs. isradipine alone; paired Student's $t$ test). The significance of L-type $\mathrm{Ca}^{2+}$ channels was further explored by measurements of glucose- and GLP-1-induced insulin secretion (Figure 2D). GLP-1 (1 pM) potentiated insulin secretion at $6 \mathrm{mM}$ glucose by $200 \%$. This effect was almost completely abrogated $(-85 \%)$ by isradipine. 500-ms depolarizations from $-70 \mathrm{mV}$ to $0 \mathrm{mV}$ increased approximately 5 -fold in response to application of $1 \mathrm{pM} \mathrm{GLP}-1$, from $7 \pm 4$ $\mathrm{fF}$ under basal conditions to $36 \pm 18 \mathrm{fF} 10$ minutes after addition of the hormone $(P<0.05$, paired Student's $t$ test; Figure 2G). In separate control experiments, no spontaneous increase in exocytosis was detected over 10 minutes in the absence of GLP-1 (Figure 2G, bottom). In addition, GLP-1 (1 pM) enhanced depolarization-evoked exocytosis in human $\beta$ cells; the responses to $36 \mathrm{fF}(P<0.05$, paired Student's $t$ test; Figure $2 \mathrm{H})$ in the absence

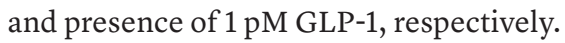

Low concentrations of GLP-1 stimulate insulin secretion by a PKA-independent mechanism. We have previously demonstrated that high (supraphysiological) concentrations of GLP-1 potentiate glucose-induced insulin secretion by a PKA-dependent mechanism (26). We confirmed that this is also the case for low (picomolar) GLP1 concentrations (Figure 3A). In these experiments, GLP-1 (1 pM) enhanced glucose-induced insulin secretion by $>175 \%$. Inclusion of the membrane-permeable PKA inhibitor myristoylated protein kinase inhibitor (myr-PKI; $1 \mu \mathrm{M}$ ) reduced the stimulatory effect of GLP- 1 by $60 \%$. Importantly, $40 \%$ of the stimulatory effect of GLP-1 was resistant to myr-PKI. Similar effects were observed with PKA, which was inhibited with 8-bromoadenosine-3', 5'-cyclic monophosphorothioate, Rp-isomer (Rp-8-Br-cAMPS) (data not shown). the first depolarization of a train averaged $95 \pm 23 \mathrm{fF}$ and $163 \pm$ 
A

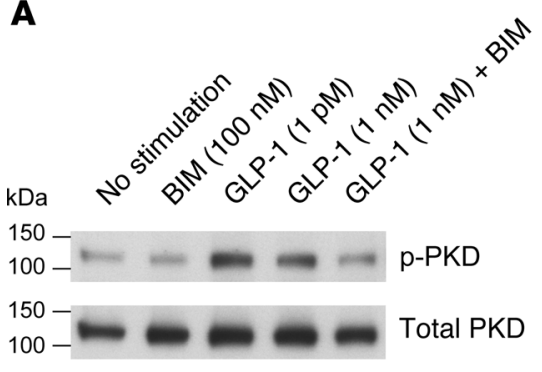

B

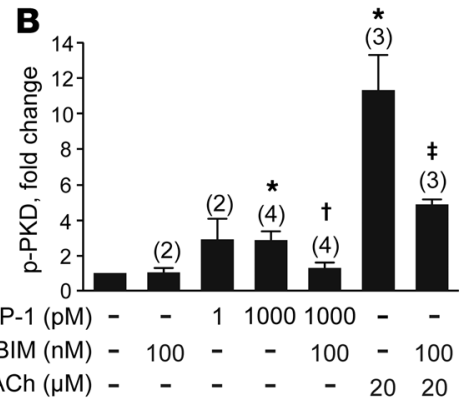

C

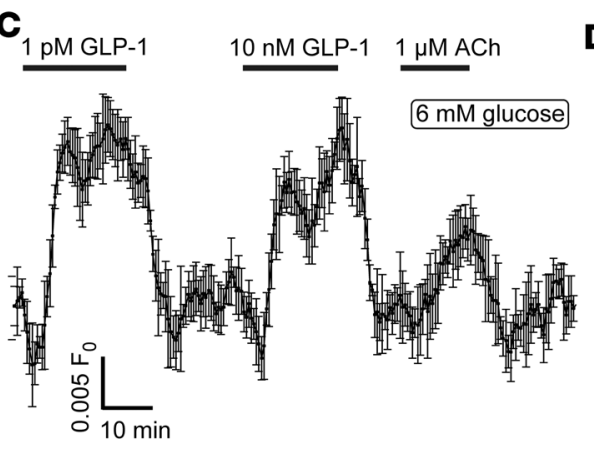

E

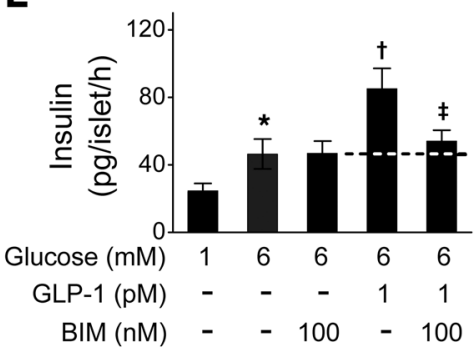

D

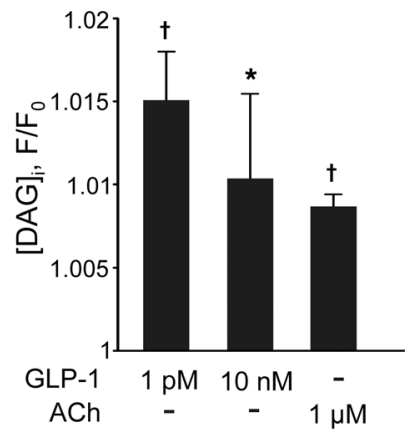

$\mathbf{F}$

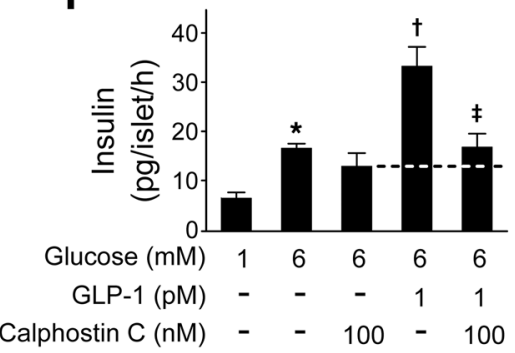

Figure 4. PKC-dependent effects of GLP-1. (A) Representative blots of activated PKD1 and total PKD1 in mouse islets. p-PKD, phosphorylated PKD1. (B) Mean fold change in activated PKD1 relative to no stimulation control in response to GLP-1 in untreated or BIM-treated islets. The number of independent experiments $(n)$ is indicated above the each bar. Mean \pm SEM (where $n>2$ ) or mean \pm range $(n=2)$. ${ }^{*} P=0.01$ vs. unstimulated; ${ }^{\dagger} P<0.05$ vs. $1 \mathrm{nM} \mathrm{GLP}-1$ alone; ${ }^{\ddagger} P$ $<0.05$ vs. ACh alone (1-way ANOVA with Dunnett's post-hoc test). (C) The effect of GLP-1 on [DAG] measured in single cells from dispersed pancreatic islets. Characteristic responses to $1 \mathrm{pM}$ and $10 \mathrm{nM}$ GLP- 1 as well as $1 \mu \mathrm{M}$ ACh (added as indicated above the trace, $n=9$ ). (D) Comparison of the effect of 1 and $10 \mathrm{pM}$ GLP-1 on [DAG], ( $n=30$ cells from 2 mice). All values are statistically higher than baseline $(P<0.05)$, apart from $10 \mathrm{nM}$ GLP-1. ${ }^{*} P<0.05$ vs. $1 \mathrm{pM}$ CLP-1; ${ }^{\dagger} P<0.05$ vs. baseline (Friedman ANOVA with Dunn-Bonferroni post-hoc test). (E and $\mathbf{F}$ ) Effects of 1 pM GLP-1 on insulin secretion in the absence and presence of the membrane-permeable PKC inhibitors (BIM, $n=9$; calphostin $C, n=4)(100 \mathrm{nM}$; introduced during 30 -minute preincubation). ${ }^{*} P<0.05$ vs. $1 \mathrm{mM}$ glucose, ${ }^{\dagger} P<0.05$ vs. $6 \mathrm{mM}$ glucose, ${ }^{\ddagger} \mathrm{P}<0.05$ vs. $6 \mathrm{mM}$ glucose plus $1 \mathrm{pM}$ GLP-1 (1-way ANOVA with Dunnett's post-hoc test).

Picomolar concentrations of GLP-1 activate $P K C$. It has been reported that GLP-1, in addition to activating PKA, activates PKC (29). Direct measurement of PKC activity using in vitro substrates requires large quantities of cells and is not feasible for studies on pancreatic islet cells. However, once activated, PKC phosphorylates numerous endogenous substrates, some of which may be used as

Like GLP-1, the adenylate cyclase activator forskolin potentiated glucose-induced insulin secretion. This effect was also reversed by myr-PKI, but the suppression was stronger than that for glucose and no myr-PKI-resistant component of secretion was observed. We conclude that the stimulatory effects of GLP-1 on insulin secretion are mediated by mechanisms that are partially PKA independent.

An indication of a PKA-independent effect was observed in human islets when PKA was inhibited by Rp-8-Br-cAMPS (Figure 3B), but this effect did not attain statistical significance.

We measured the effect of increasing concentrations of GLP-1 on cytoplasmic cAMP levels $\left([\mathrm{cAMP}]_{\mathrm{i}}\right.$ ) in pancreatic islet cells using the genetically encoded Förster resonance energy transfer (FRET) reporter Epac2-camps (27). GLP-1 at concentrations below $1 \mathrm{nM}$ had no effect on [cAMP $]_{i}$, whereas higher concentrations ( $\geq 1 \mathrm{nM}$ ) consistently increased [cAMP] $]_{\mathrm{i}}$ (Figure $3 \mathrm{C}$ ), with an $\mathrm{EC}_{50}$ of $5.7 \pm 0.9 \mathrm{nM}$ (Figure 3D).

We monitored PKA activity using an AKAR3 FRET sensor (28). In agreement with the cAMP measurements, addition of GLP-1 (1 pM) did not result in any activation of PKA, regardless of whether the experiments were conducted in the absence or presence of myr-PKI, but the response to the combination of forskolin and 3-isobutyl-1-methylxanthine was reduced by approximately $70 \%$ in the presence of myr-PKI (Figure 3E). Basal PKA activity (measured as the initial YFP/CFP ratio) was reduced in cells treated with myr-PKI (Figure 3F). a downstream readout of its activity. PKC is known to phosphorylate and activate protein kinase D1 (PKD1) (30). We assessed the levels of activated endogenous PKD1 under basal conditions and in the presence of $1 \mathrm{pM}$ or $1 \mathrm{nM}$ GLP-1 with Western blotting, using antibodies specific for phosphorylated PKD1. Acetylcholine (ACh; $20 \mu \mathrm{M}$ ), an agonist known to cause PKC activation in $\beta$ cells (31), was used as a positive control. As shown in Figure 4, A and $\mathrm{B}$, stimulation of islets with $1 \mathrm{pM}$ or $1 \mathrm{nM} \mathrm{GLP}-1$ increased PKD1 phosphorylation by an average of $200 \%$. GLP- 1 had virtually identical effects in the absence and presence of the ATP-regulated $\mathrm{K}^{+}$ $\left(\mathrm{K}_{\mathrm{ATP}}\right)$ channel activator diazoxide $(100 \mu \mathrm{M})$, indicating that the activation of PKC by GLP-1 is not secondary to the stimulation of electrical activity (data not shown). In parallel measurements, ACh increased PKD1 phosphorylation by $>1,000 \%$. The effects of both GLP-1 and ACh were reversed by bisindolylmaleimide (BIM), consistent with the idea that activation of PKD1 is mediated by activation of PKC.

We also measured the effect of GLP-1 on the submembrane levels of diacylglycerol ([DAG $\left.]_{i}\right)$ in pancreatic islet cells using a genetically encoded probe, Upward DAG (32). Addition of GLP-1 at concentrations as low as $1 \mathrm{pM}$ resulted in a rapid and reversible increase in $[D A G]_{i}$ levels (Figure 4C). Notably, application of a 10,000-fold higher concentration of GLP-1 did not result in a further increase in $[D A G]_{i}$ (Figure 4, C and D). In fact, the response to the high concentration of GLP-1 was, if anything, lower than that produced by 1 


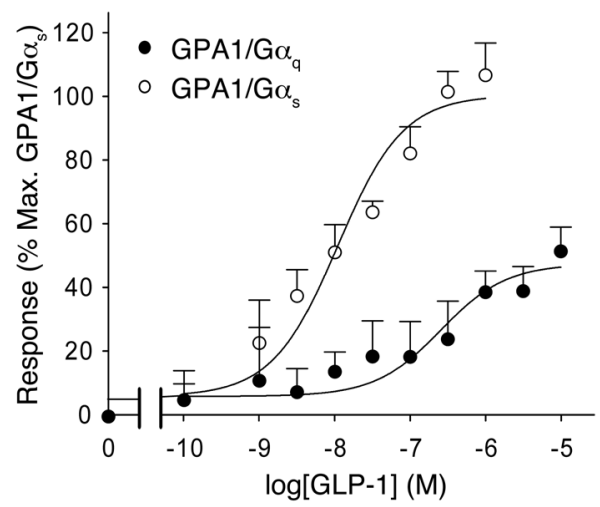

$\mathrm{pM}$. ACh, when used at the low concentration of $1 \mu \mathrm{M}$, also evoked a small increase in $[D A G]_{i}$. We conclude that 1 pM GLP- 1 is a fairly strong activator of PLC, with a resultant increase in $[D A G]_{i}$.

We confirmed the involvement of PKC in the stimulatory effect of GLP-1 on insulin secretion using the PKC inhibitors BIM and calphostin C (Figure 4, E and F). Both compounds abolished the stimulatory effect of GLP-1.

Human GLP-1R functionally activates a $G_{a q}$ chimera. It is well established that the GLP-1R activates $G_{a s}$ and thereby increases cAMP production. However, it has been suggested that GLP-1 can also bind to $\mathrm{G}_{\mathrm{ai}}$ and $\mathrm{G}_{a \mathrm{q}}(20-23)$, which are linked to activation of PLC, generation of DAG, and activation of PKC. We coexpressed the GLP-1R with mammalian $G_{a s}$ and $G_{a q}$ as previously described (33). Stimulation of the GLP-1R expressed in the $G_{a q}$-containing yeast strain resulted in a robust response (Figure 5).

cAMP/PKA-independent and PLC/PKC-dependent effects of GLP-1. We tested the effects of low concentrations of GLP-1 on electrical activity in the presence of the PKA inhibitors
Figure 5. Activation of $\mathbf{G} \alpha_{q}$ by GLP-1. Dose-response curves of GLP-1 in yeast strains expressing $\mathrm{GPA} 1 / \mathrm{G} \alpha_{\mathrm{q}}$ and $\mathrm{GPA} 1 / \mathrm{G} \alpha_{\mathrm{s}}$ chimaeras. Activation of the reporter gene was calculated as a percentage of the maximum response observed ( $n=7-8$ experiments).

Rp-8-Br-cAMPS and myr-PKI (Figure 6A). Unexpectedly, and unlike what has been previously reported for high concentrations of the hormone (26), 1 pM GLP-1 remained capable of initiating electrical activity under these experimental conditions. This effect appeared qualitatively similar to that observed under control conditions (cf. Figure 1D).

The stimulatory effect of low concentrations of GLP-1 was mimicked by the PKC activator PMA (Figure 6B). Like GLP-1, PMA depolarized the $\beta$ cell and initiated action potential firing. In the presence of PMA, GLP-1 exerted no additive stimulatory effect (data not shown). Application of U73122, an inhibitor of PLC, reversibly antagonized the stimulatory effect of GLP-1 on $\beta$ cell electrical activity (Figure $6 \mathrm{C}$ ), in agreement with a previous report (29).

Collectively, the data in Figures 3 to 6 suggest that GLP-1 depolarizes the $\beta$ cell and triggers action potential firing by a PKA-independent but PKC-dependent mechanism that involves activation of PLC by $\mathrm{G}_{a q}$-coupled GLP-1Rs.

$K_{A T P}$ channel-dependent and-independent effects of GLP-1. It has previously been reported that high concentrations of GLP-1 stimulate electrical activity and insulin secretion by inhibition of $\mathrm{K}_{\text {ATP }}$ channels (12-15). Application of 1 pM GLP-1 was without detectable inhibitory effect on whole-cell membrane conductance in the presence of $6 \mathrm{mM}$ glucose (Figure 7, A and B). We confirmed that $\mathrm{K}_{\mathrm{ATP}}$ channel activity, albeit at a low level, persisted in the presence of $6 \mathrm{mM}$ glucose (Figure 7, C and D).
Figure 6. PKA-independent stimulation of $\beta$ cell electrical activity. (A) Representative membrane potential recording from a single $\beta$ cell pretreated with $100 \mu \mathrm{M}$ $\mathrm{Rp}-8$-Br-cAMPS ( $n=4$ cells from 2 mice) or myr-PKI ( $n=4$ cells from 2 mice, not shown). Note initiation of electrical activity by GLP-1 in the presence of Rp-8-Br-cAMPS. (B) Effect of the PKC activator PMA on membrane potential ( $n=5$ cells from 4 mice). (C) Effect of the PLC inhibitor U73122 on action potential firing triggered by 1 pM GLP-1 ( $n=8$ cells from 6 mice). Note reversible inhibition. All measurements were performed using the perforated patch whole-cell technique in the presence of $6 \mathrm{mM}$ glucose.
A

$1 \mathrm{pM}$ GLP-1

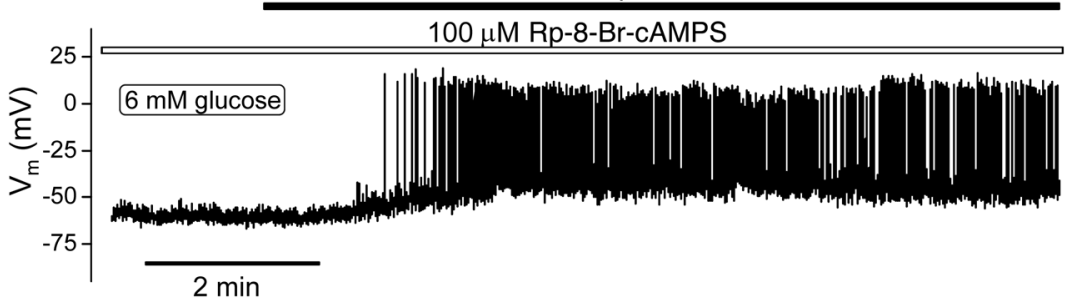

B

100 nM PMA

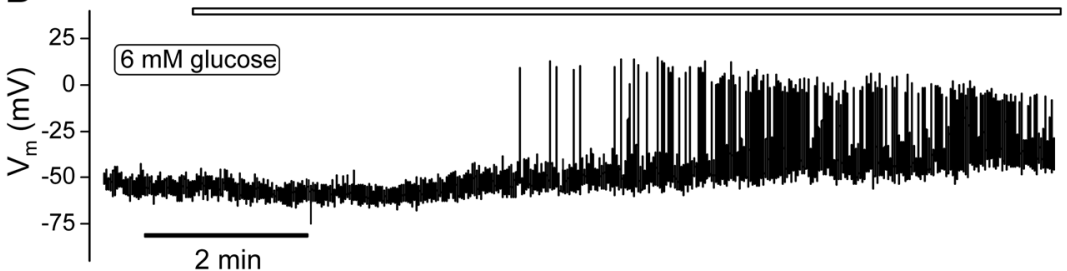

$2 \min$

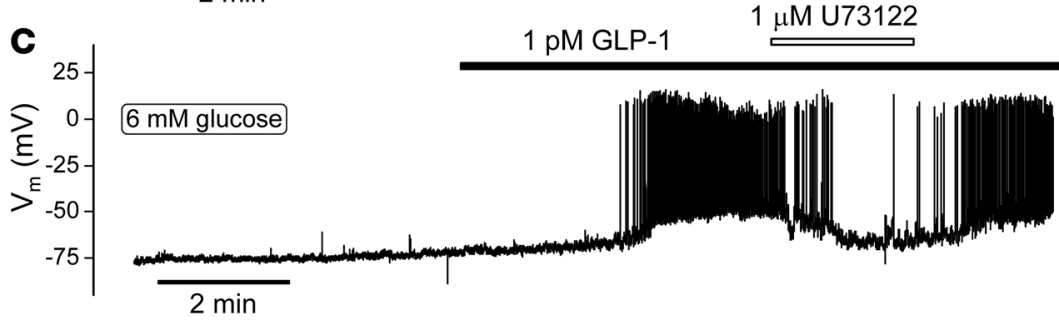


A
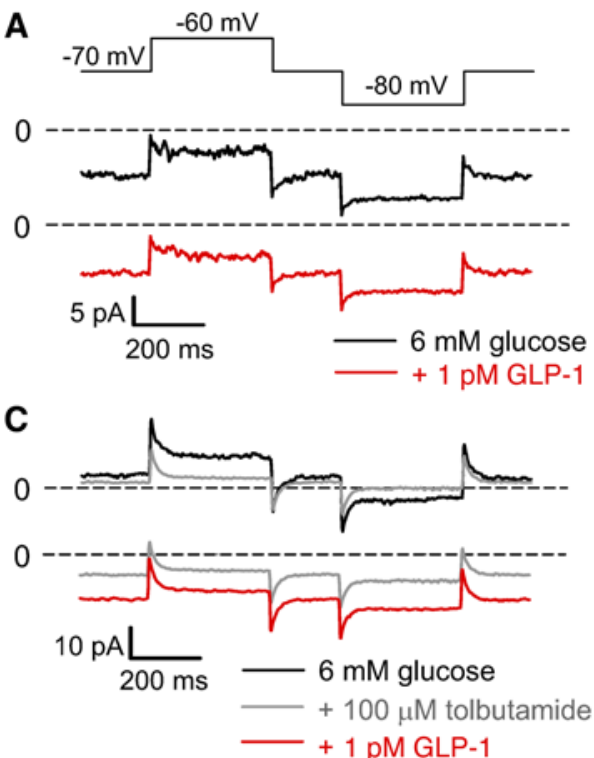

B

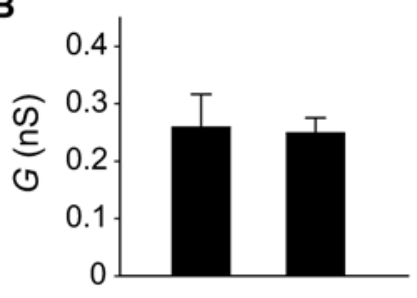

GLP-1 (pM) - $\quad 1$

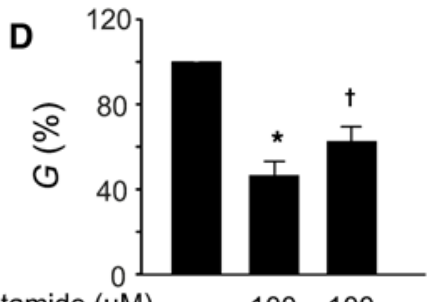

Tolbutamide $(\mu \mathrm{M}) \quad-\quad 100 \quad 100$

GLP-1 (pM) - - 1
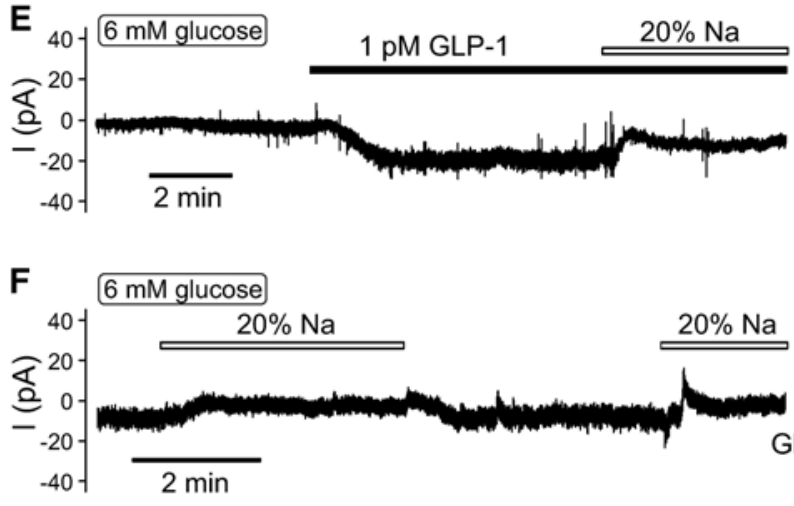

\section{G}

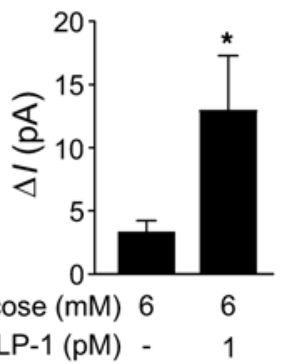

Figure 7. Physiological concentrations of GLP-1 activate a depolarizing membrane current in $\beta$ cells. (A) Whole-cell resting currents activated by application of $\pm 10 \mathrm{mV}$ voltage pulses from a holding potential of $-70 \mathrm{mV}$. Measurements were made at $6 \mathrm{mM}$ glucose alone (black trace) and 10 minutes after addition of 1 pM GLP-1 (red trace). (B) Summary of effects of 1 pM GLP-1 on resting membrane conductance (C) calculated from the experiments in A. Note that GLP-1 is without a detectable inhibitory effect ( $n=4$ cells from 4 mice). (C) As in $\mathbf{A}$ but testing responses at 6 $\mathrm{mM}$ glucose alone (black trace) after addition of 100 $\mu \mathrm{M}$ tolbutamide (gray trace) and following addition of GLP-1 in the continued presence of glucose and tolbutamide (red trace). (D) Summary of effects of tolbutamide and GLP-1 on membrane conductance $(G)$ calculated from the current excursions in response to voltage pulses (C) and expressed as a percentage of that at $6 \mathrm{mM}$ glucose. ${ }^{*} P<0.05$ vs. 6 mM glucose; ${ }^{\dagger} P<0.05$ vs. 6 glucose plus tolbutamide ( $n=5$ from 4 mice; 1-way ANOVA with Dunnett's post-hoc test). (E) Membrane current at $-70 \mathrm{mV}$ recorded in the presence of $6 \mathrm{mM}$ glucose before and after addition of $1 \mathrm{pM} \mathrm{GLP-1}$ and effect of lowering [ $\left.\mathrm{Na}^{+}\right]$from $140 \mathrm{mM}$ to $28 \mathrm{mM}$ ("20\% Na+"). (F) As in E but showing effects of lowering $\left[\mathrm{Na}^{+}\right]_{0}$ in the presence of $6 \mathrm{mM}$ glucose alone. (G) Histogram summarizing effects of lowering $\left[\mathrm{Na}^{+}\right]_{0}$ on the current at -70 $\mathrm{mV}(\Delta l)$ in the presence of $6 \mathrm{mM}$ glucose alone $(n=8$ cells from 4 mice) or in the presence of $6 \mathrm{mM}$ glucose and $1 \mathrm{pM} \mathrm{GLP}-1$ ( $n=6$ cells from 4 mice). ${ }^{*} P<0.01$ vs. normal $\left[\mathrm{Na}^{+}\right]_{0}$ (Student's $t$ test) All measurements in this figure were performed using the perforated patch whole-cell technique.
Thus, addition of the $\mathrm{K}_{\mathrm{ATP}}$ channel blocker tolbutamide reduced membrane conductance by $50 \%$. Interestingly, addition of GLP-1 $(1 \mathrm{pM})$ in the continued presence of tolbutamide increased the whole-cell membrane conductance.

We characterized this $\mathrm{K}_{\mathrm{ATP}}$ channel-independent conductance by whole-cell voltage-clamp measurements. In $6 \beta$ cells, application of GLP-1 evoked an inward current when holding at $-70 \mathrm{mV}$ that averaged $-9 \pm 2$ pA $(P<0.001$, paired Student's $t$ test; Figure $7 \mathrm{E})$. Reduction of extracellular $\mathrm{Na}^{+}$in the presence of GLP-1 abolished this current and reduced the holding current by $13 \pm 4 \mathrm{pA}(P<0.01$, paired Student's $t$ test). When extracellular $\mathrm{Na}^{+}$was reduced in the presence of $6 \mathrm{mM}$ glucose alone (i.e., without GLP-1), the reduction of the holding current was much smaller and amounted to only $3 \pm$ $1 \mathrm{pA}$ (Figure 7, F and G). Thus, we conclude that GLP-1 depolarizes the $\beta$ cell by activation of $\mathrm{Na}^{+}$-permeable conductance that is activated to a much lower extent by glucose alone. The latter conclusion is in agreement with the reported weak effects of $\mathrm{Na}^{+}$removal on glucose-induced electrical activity (34).

$K_{\text {ATP }}$ channel-independent effect is mediated by activation of TRPM4 and TRPM5 channels. We used pharmacological ion channel blockers to establish the electrophysiological basis underlying the stimulatory effects of low concentrations of GLP- 1 on $\beta$ cell electrical activity. We first ascertained that GLP-1 remains capable of stimulating $\beta$ cell electrical activity, even when $\mathrm{K}_{\mathrm{ATP}}$ channel activity has been pharmacologically suppressed. Figure 8 shows membrane potential recordings from mouse and human $\beta$ cells exposed to $6 \mathrm{mM}$ glucose. Whereas mouse $\beta$ cells are electrically silent at this glucose concentration, human $\beta$ cells are electrically active and fire spontaneous action potentials at a high frequency. In both mouse and human $\beta$ cells, addition of the $\mathrm{K}_{\text {ATP }}$ channel blocker tolbutamide resulted in membrane depolarization and stimulation of action potential firing. The cells were then hyperpolarized, and action potential firing was reduced by injection of negative current. In the hyperpolarized mouse $\beta$ cells exposed to tolbutamide, addition of GLP-1 still resulted in a 60-fold increase in action potential firing, from $0.06 \pm 0.03 \mathrm{~Hz}$ in the presence of glucose and tolbutamide alone to $3.6 \pm 0.6 \mathrm{~Hz}$ in the presence of GLP-1 $(P<0.005$, paired Student's $t$ test). In similarly hyperpolarized human $\beta$ cells, 1 pM GLP-1 increased action potential firing in the presence of tolbutamide $>25$-fold (Figure $8 \mathrm{~B}$ ), from a basal rate of $0.04 \pm 0.02 \mathrm{~Hz}$ to $1.1 \pm 0.74 \mathrm{~Hz}(P<0.001$, paired Student's $t$ test). These experiments suggest that GLP-1 depolarizes mouse and human $\beta$ cells by a mechanism that is (at least partially) $\mathrm{K}_{\mathrm{ATP}}$ channel independent.

In addition, we tested the effects of GLP-1 on electrical activity in mouse $\beta$ cells in the presence of the L-type $\mathrm{Ca}^{2+}$ channel blocker isradipine. As shown in Figure 8C, isradipine inhibited action potential firing. GLP-1 application in the presence 
A
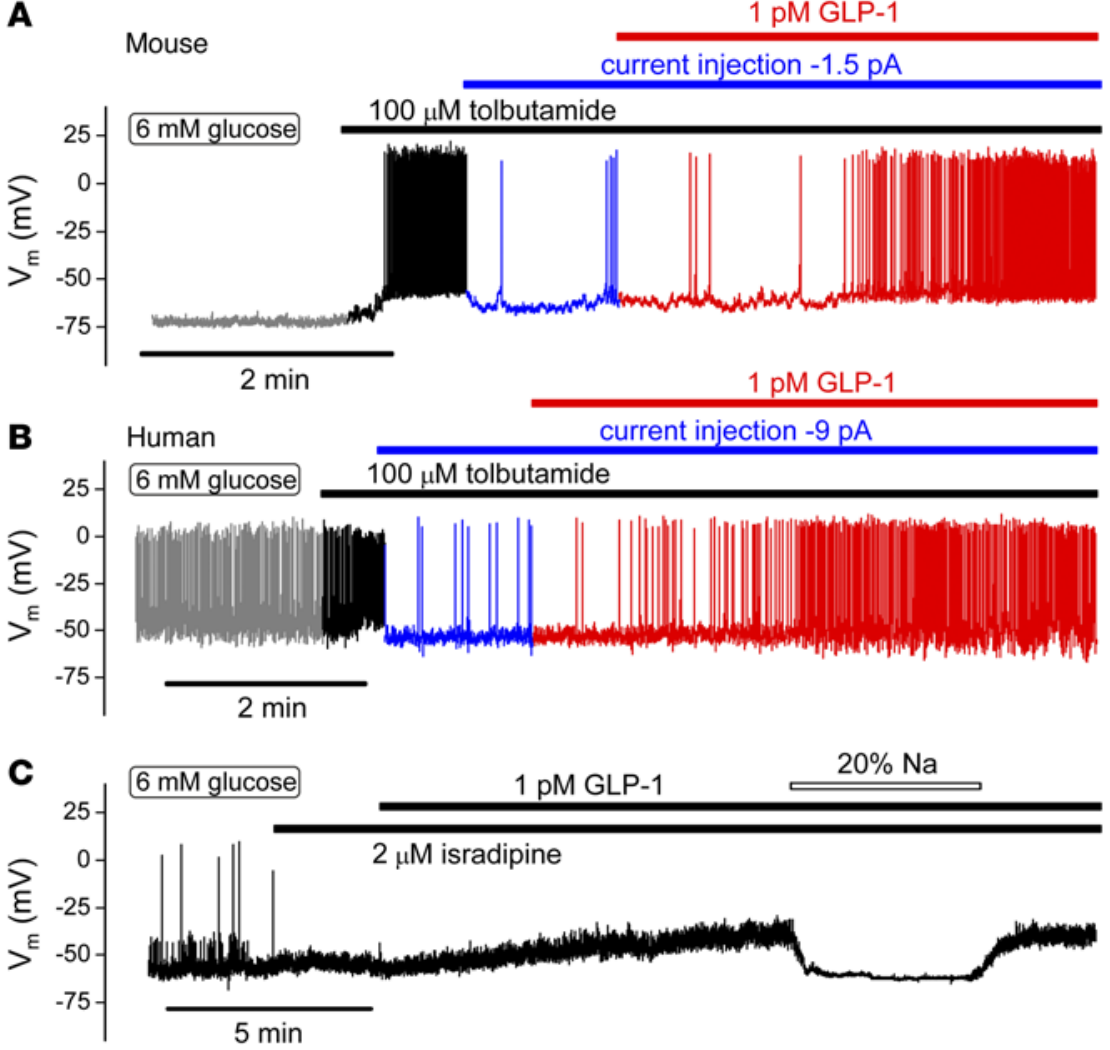

Figure 8. GLP-1 stimulates electrical activity by activation of a $\mathrm{Na}^{+}$-dependent and $\mathrm{K}_{\mathrm{ATP}}$ channelindependent mechanism. (A and $B$ ) Membrane potential recording from (A) mouse ( $n=6$ cells from 2 mice) and (B) human ( $n=4$ cells from 3 donors) $\beta$ cells. Tolbutamide and GLP-1 were added as indicated above traces. Electrical activity in the presence of glucose and tolbutamide was suppressed by injection of hyperpolarizing current (-1.5 pA in $\mathbf{A}$ and -9 pA in $\mathbf{B}$ as indicated) in the different experiments. For clarity, the recordings have been color coded (gray, $6 \mathrm{mM}$ glucose; black, after addition of tolbutamide; blue, after injection of hyperpolarizing current; red, after application of GLP-1). (C) GLP-1 remains capable of depolarizing mouse $\beta$ cells in the presence of the L-type $\mathrm{Ca}^{2+}$ channel blocker isradipine but does not evoke action potential firing $(n=6$ from 3 mice). The depolarizing action of CLP-1 was reversibly suppressed by lowering $\left[\mathrm{Na}^{+}\right]$to $28 \mathrm{mM}$ ("20\% Na") ( $n=3$ from 2 mice).

This observation is in good agreement with the finding that only $5 \%$ of the $\beta$ cells are electrically active and generate $\mathrm{Ca}^{2+}$ oscillations at $6 \mathrm{mM}$ glucose (Figure 1E). We conclude, in agreement with earlier reports $(25,36)$, that increasing glucose concentrations stimulate insulin secretion by recruitment of $\beta$ cells.

We explored the functional significance of isradipine remained capable of depolarizing the $\beta$ cell but was without stimulatory effect on action potential firing, consistent with the important role played by L-type $\mathrm{Ca}^{2+}$ channels in $\beta$ cell electrical activity (35) and secretion (Figure 2D). In the absence of regenerative electrical activity, the effect of GLP-1 on the $\beta$ cell membrane potential could be accurately measured. Under these conditions, $1 \mathrm{pM}$ GLP-1 depolarized the $\beta$ cells by $11 \pm 2 \mathrm{mV}(P<0.01$, paired Student's $t$ test), an effect that was fully reversed upon lowering of extracellular $\mathrm{Na}^{+}$concentration $\left(\left[\mathrm{Na}^{+}\right]_{\mathrm{o}}\right)\left(20 \%\right.$ of normal $\left.\left[\mathrm{Na}^{+}\right]_{\mathrm{o}}\right)$. Thus, the depolarizing effect of GLP-1 was not mediated by activation of L-type $\mathrm{Ca}^{2+}$ channels but rather a conductance permeable to $\mathrm{Na}^{+}$(cf. Figure 7E).

Role of TRPM4 and TRPM5 channels in electrical activity and insulin secretion evoked by GLP-1. Preliminary experiments suggested that the stimulatory effects of GLP-1 on electrical activity and insulin secretion were sensitive to 9-phenanthrol, an inhibitor of $\mathrm{Ca}^{2+}$-activated TRPM4 $\mathrm{Na}^{+}$-permeable ion channels (ref. 23 and Supplemental Figure 1, A and B; supplemental material available online with this article; doi:10.1172/JCI81975DS1). We explored this possibility further by comparing the effects of GLP-1 on insulin secretion in islets from wild-type and Trpm $4^{-/}$mice. We also tested the effects of ablating TRPM5 channels, which are expressed in pancreatic $\beta$ cells and similarly regulated (23).

In wild-type islets, the stimulatory effect of $6 \mathrm{mM}$ glucose was potentiated by approximately $85 \%$ in the presence of $10 \mathrm{pM} \mathrm{GLP}-1$ (Figure 9A), an effect that did not occur in Trpm $4^{-/}$islets (Figure 9B) or Trpm5 $5^{--}$islets (Figure 9C). By contrast, Trpm $4^{-/}$and Trpm5 $5^{-1-}$ islets remained as responsive as wild-type islets to glucose (Supplemental Figure 2, A-C). In wild-type islets, insulin secretion above basal $(1 \mathrm{mM})$ was $>15$-fold higher at $20 \mathrm{mM}$ glucose than at $6 \mathrm{mM}$. of TRPM4 and TRPM5 channels further by membrane potential recordings. Trpm $4^{--} \beta$ cells retained some limited responsiveness to GLP-1 (Figure 9E), but the effect was weak compared with that in wild-type cells (Figure 9D). BCells in Trpm5-/islets were completely refractory to stimulation with GLP-1 (Figure 9F). The effects of GLP-1 on action potential firing in wild-type, Trpm $4^{-/}$, and Trpm $5^{-/-}$ $\beta$ cells are summarized in Figure 9G. The strong suppression of insulin secretion evoked by GLP-1 in Trpm $4^{--}$and $\operatorname{Trpm} 5^{-/}$islets is echoed by equally strong reductions in action potential firing.

GLP-1 increases $\left[\mathrm{Ca}^{2+}\right]_{i}$ in hyperpolarized $\beta$ cells. How does GLP- 1 activate the TRPM4 and TRPM5 channels? It has been reported that GLP-1 increases the islet content of NAADP (37), which may release $\mathrm{Ca}^{2+}$ from intracellular acidic stores by activation of two-pore channel 1 (TPC1) or TPC2 (38). This would provide a potential link between GLP-1 and activation of TRPM4 and TRPM5 channels, which are $\mathrm{Ca}^{2+}$ activated (37). We investigated this using Tpc1 Tpc2 double KO (DKO) mice. However, $T p c 1$ Tpc2 DKO islets retained full responsiveness to GLP-1 with regard to both secretion (Figure 10, A and B) and electrical activity (Figure 10C). Tpc1 Tpc2 DKO islets were also responsive to $20 \mathrm{mM}$ glucose (Supplemental Figure 3, A and B)

Activation of PLC by GLP-1 (see above) could be expected to increase $\left[\mathrm{Ca}^{2+}\right]_{\mathrm{i}}$ by InsP--dependent mobilization from intracellular stores. To address this possibility, we measured $\left[\mathrm{Ca}^{2+}\right]_{i}$ in isolated $\beta$ cells. In agreement with the $\left[\mathrm{Ca}^{2+}\right]_{i}$ measurements in intact pancreatic islets (Figure 1E), application of 1 pM GLP-1 in the presence of $6 \mathrm{mM}$ glucose consistently induced rapid $\left[\mathrm{Ca}^{2+}\right]_{\mathrm{i}}$ oscillations (Figure 10D). We then repeated the experiment in the presence of the $\mathrm{K}_{\text {ATP }}$ channel activator diazoxide $(200 \mu \mathrm{M})$. Application of diazoxide reduced basal $\left[\mathrm{Ca}^{2+}\right]_{i}$ at $6 \mathrm{mM}$ glucose. Interest- 

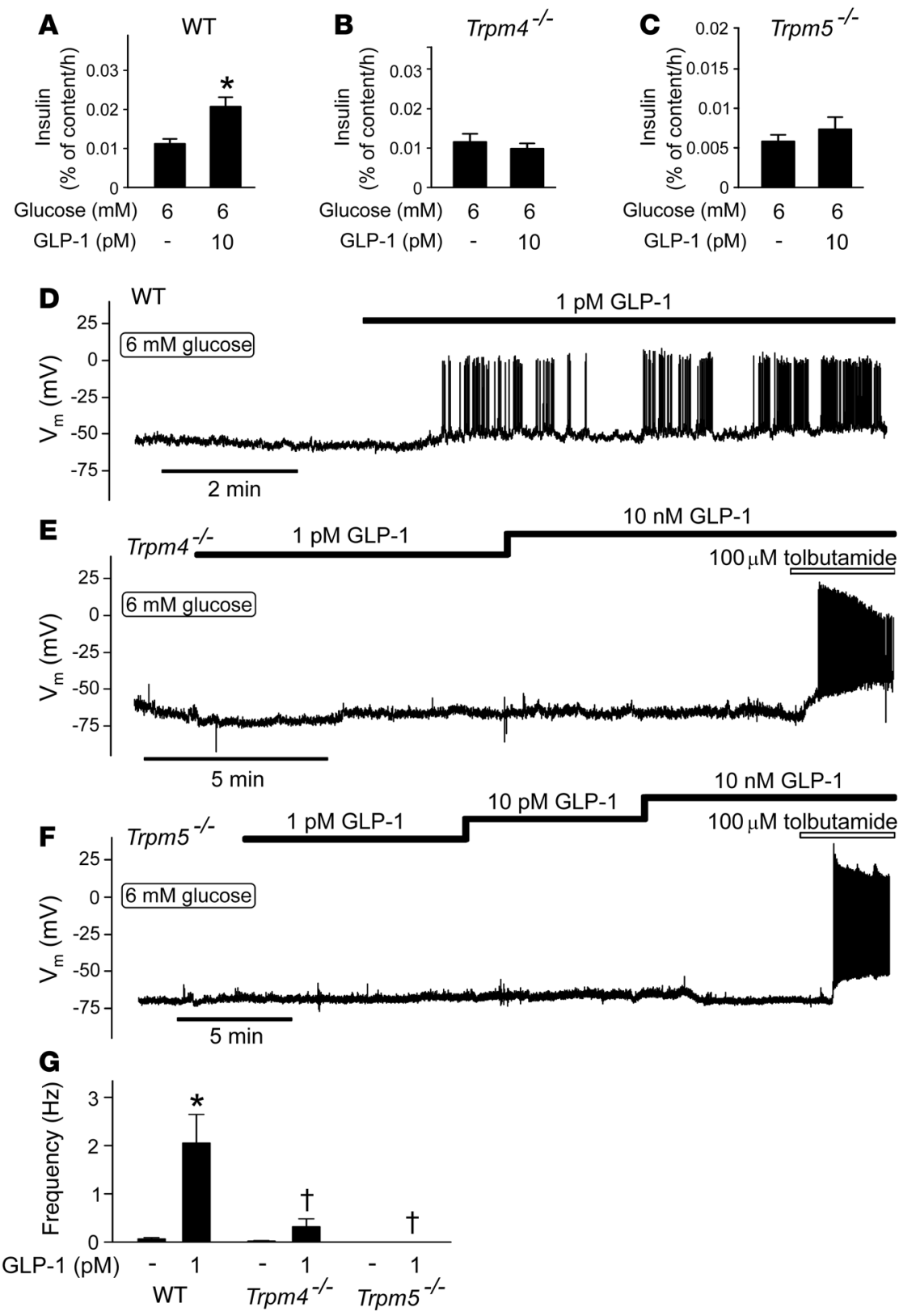

ingly, application of GLP-1 (1 pM) in the presence of diazoxide still increased $\left[\mathrm{Ca}^{2+}\right]_{i}$, but the effect was smaller and did not exhibit any oscillations but only an increase to a new plateau level (Figure 1OE). The experiments were concluded by membrane depolarization produced by increasing the extracellular $\mathrm{K}^{+}$concentration $\left(\left[\mathrm{K}^{+}\right]_{\mathrm{o}}\right)$ to 50 $\mathrm{mM}$. This invariably elicited a large increase in $\left[\mathrm{Ca}^{2+}\right]_{\mathrm{i}}$, both in the absence and presence of diazoxide. When GLP-1 was applied in the presence of diazoxide and to cells pretreated with thapsigargin (1 $\mu \mathrm{M})$, no GLP-1-induced increase in $\left[\mathrm{Ca}^{2+}\right]_{i}$ was observed (Figure 10F).

Finally, we ascertained that GLP-1 did not evoke electrical activity in the presence of the $\mathrm{K}_{\mathrm{ATP}}$ channel activator diazoxide. When applied to $\beta$ cells exposed to $6 \mathrm{mM}$ glucose, diazoxide (200 $\mu \mathrm{M})$ hyperpolarized the membrane potential to $-80 \pm 1 \mathrm{mV}$. Application of GLP-1 induced a reversible depolarization of $10 \pm 4 \mathrm{mV}$ $(P<0.05$, paired Student's $t$ test $)$ but did not evoke action potential firing (Figure 10G).
Figure 9. GLP-1 acts by a TRPM4- and TRPM5-dependent mechanism. (A-C) Effects of 10 pM GLP-1 on insulin secretion in islets from (A) wild-type, (B) $\mathrm{Trpm}^{-/-}$, and (C) Trpm5 $5^{-/-}$mice exposed to $6 \mathrm{mM}$ glucose. ${ }^{*} P<0.05$ vs. 6 mM glucose $(n=6$ islets from 7-9 mice; 1-way ANOVA with Dunnett's posthoc test). (D-F) Effects of GLP-1 (1 pM to $10 \mathrm{nM}$ ) on electrical activity in (D) wild-type $(n=5$ cells from 2 mice), (E) Trpm4 ${ }^{-/-}$( $n=9$ cells from 5 mice), and (F) $\operatorname{Trpm5}^{-1-}$ ( $n=7$ cells from 5 mice) $\beta$ cells isolated from C57BL6/N mice. (C) Histogram summarizing action potential frequency in $\beta$ cells exposed to 6 $\mathrm{mM}$ glucose in the absence or presence of GLP-1 glucose in wild-type, Trpm4 $4^{-1-}$, and Trpm5 $5^{-1-} \beta$ cells as in D-F. ${ }^{*} P<0.05$ vs. 6 mM glucose (Student's $t$ test); ${ }^{\dagger} P<0.05$ vs. 6 mM glucose plus GLP-1 (wild-type; 1-way ANOVA with Dunnett's post-hoc test).

\section{Discussion}

We have revisited the mechanisms by which GLP-1 stimulates insulin secretion in mouse and human $\beta$ cells. Most previous in vitro studies have been conducted in cell lines or using rodent islets, and it is not immediately evident to what extent these findings can be extended to humans. Another problem is that most in vitro studies have employed very high concentrations of GLP-1 (1,000- to 10000fold higher than the peripheral plasma concentration). Here, we have characterized the effects of physiological concentrations of GLP-1 (1-10 pM) on insulin secretion and electrical activity. We show that such low concentrations are as effective (if not more effective) as the higher concentrations previously employed. We dissect the signal transduction pathways involved and provide evidence for the involvement of a PLC/PKC-dependent mechanism, culminating in the activation of a $\mathrm{Na}^{+}$-permeable conductance. Here, we discuss key aspects of this work. We first consider the mechanism by which physiological concentrations exert the stimulatory effect on the $\beta$ cell. We then turn to the functional implications of our findings and the impact they have on the mechanism of action of GLP-1 in vivo. Figure 11 summarizes schematically the effects of low concentrations of GLP- 1 on $\beta$ cell signal transduction pathways that culminate in stimulation of insulin secretion.

Picomolar concentrations of GLP-1 stimulate insulin secretion by PKC-dependent mechanisms. We found that a large component of the stimulatory effect of GLP-1 on glucose-stimulated insulin secretion was sensitive to inhibitors of PKA (such as Rp-8-Br-cAMPS and myr-PKI). Unexpectedly, $40 \%$ of the stimulatory effect on insulin secretion persisted in the presence of myr-PKI and GLP-1 remained capable of stimulating $\beta$ cell electrical activity in the presence of PKA inhibitors.

We believe that the PKA-resistant component depends on PKC activity. This is suggested by the observation that the PKC inhibitors BIM and calphostin $\mathrm{C}$ abolished the stimulatory effect 


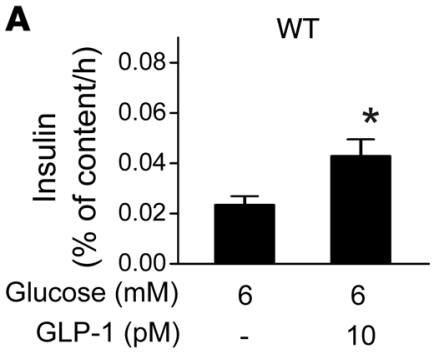

A
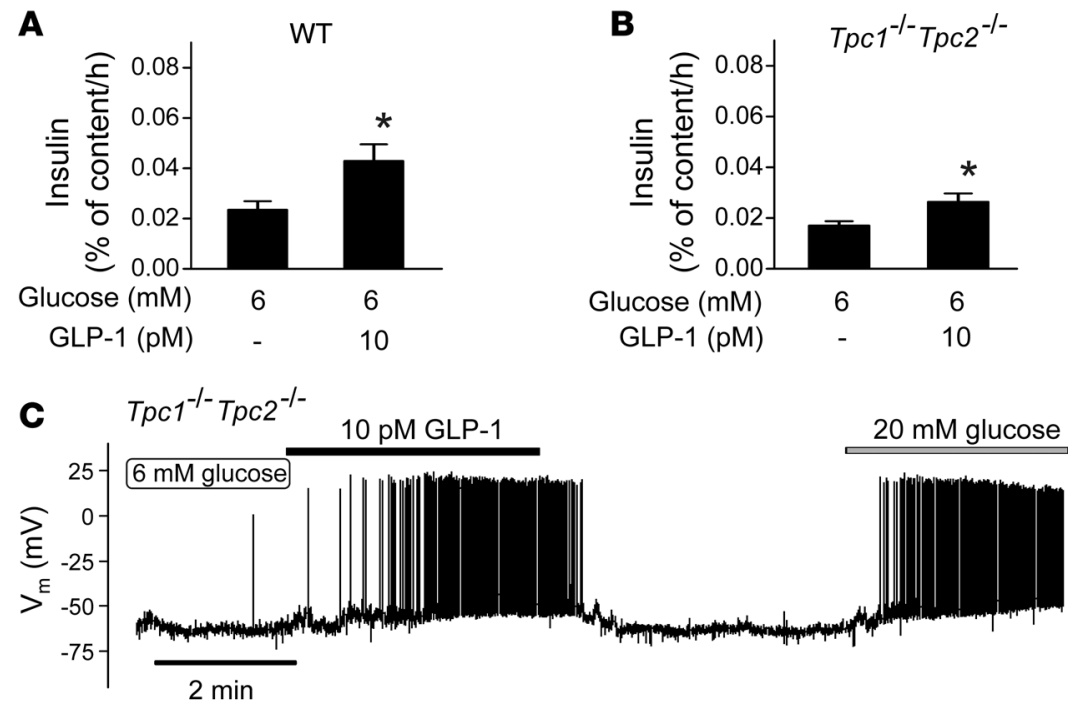

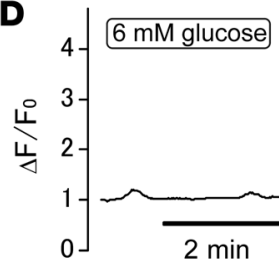

F
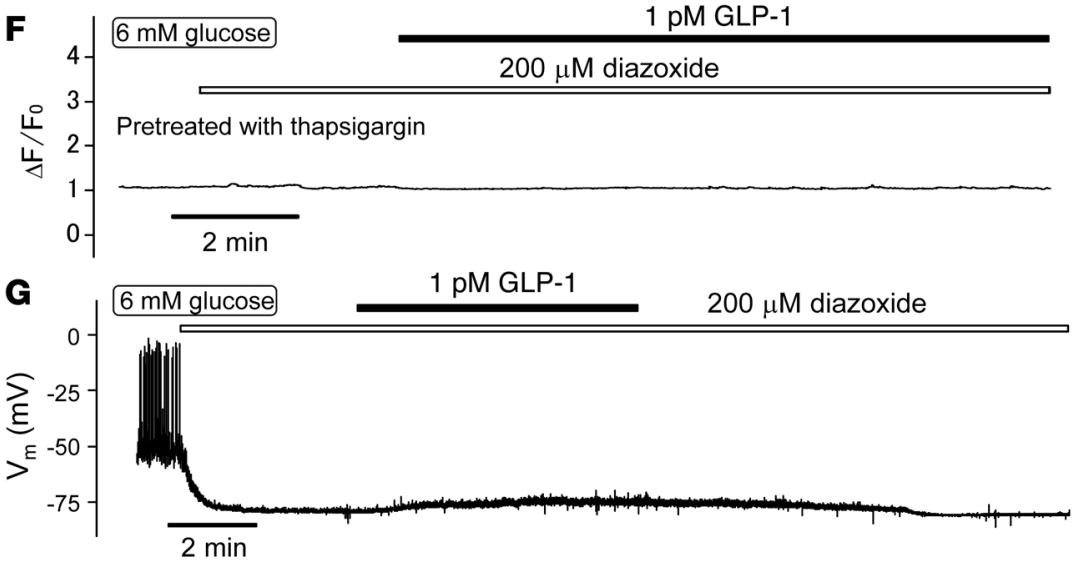

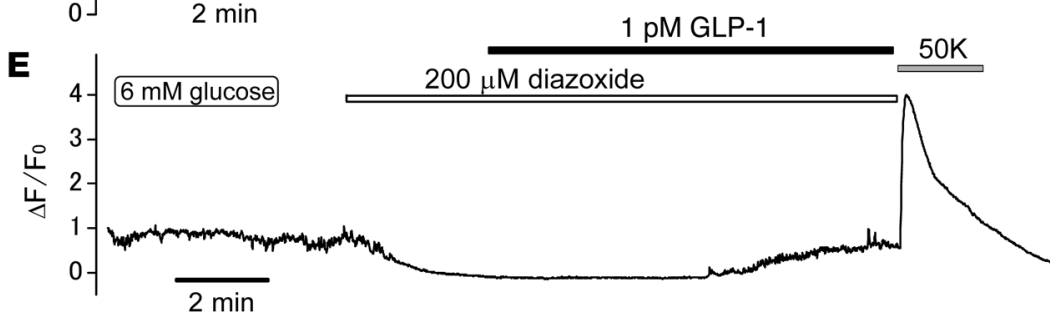

Figure 10. GLP-1 mobilizes intracellular $\mathrm{Ca}^{2+}$. (A and $\left.\mathrm{B}\right)$ Effects of CLP-1 (10 pM) on insulin secretion in islets from (A) wild-type and (B) Tpc1 Tpc2 DKO mice exposed to 6 mM glucose ( $n=7-8$ islets from $6-7$ mice). ${ }^{*} P<0.05$ vs. 6 $\mathrm{mM}$ glucose (1-way ANOVA with Dunnett's post-hoc test). (C) Effects of $10 \mathrm{pM}$ GLP-1 on electrical activity in Tpc1 Tpc2 DKO $\beta$ cells. Note that GLP-1 stimulates electrical activity in Tpc1 Tpc2 DKO $\beta$ cells $(n=4)$. (D-F) Change in fluo-3 fluorescence $\left(\Delta F / F_{0}\right)$ measured in single cells in small islet cell clusters from NMRI mice. Diazoxide (200 $\mu \mathrm{M}), \mathrm{CLP}-1(1 \mathrm{pM}),\left[\mathrm{K}^{+}\right]_{0}(50 \mathrm{mM})$, and thapsigargin $(1 \mu \mathrm{M})$ were applied as indicated by horizontal lines. Representative traces of 7 to 12 cells from 3 to 7 experiments. (G) Failure of GLP-1 to evoke electrical activity in the presence of diazoxide $(200 \mu \mathrm{M})$. Clucose was present at a concentration of $6 \mathrm{mM}$ throughout. Note spontaneous action potential firing at $6 \mathrm{mM}$ glucose, suppression of action potential firing, and membrane repolarization evoked by application of diazoxide and small and reversible depolarization produced by GLP-1 ( $n=6$ from 4 mice).

cal inhibition of PLC abolished the stimulation of $\beta$ cell electrical activity induced by GLP-1. Third, application of GLP-1 at picomolar concentrations led to an increased intracellular concentration of DAG (Figure 4, C and D).

It may seem surprising that the PKC inhibitors abolished the stimulatory effect on insulin secretion, given that the PKA-resistant component of GLP-1-induced secretion only amounted to $40 \%$ of the total stimulatory effect. This we attribute to a hierarchy of the PLC/PKC- and PKA-dependent effects. Whereas PKC is required for the initiation of electrical activity and stimulation of $\mathrm{Ca}^{2+}$ influx, the PKA-dependent mechanism principally potentiates the downstream effects by enhanced $\mathrm{Ca}^{2+}$-dependent exocytosis. Thus, the PKAdependent effects will not operate in the absence of electrical activity (which is PKC dependent).

In addition to the PKA- and PKC-dependent effects we discuss above, GLP-1 has also been postulated to activate the low-affinity cAMP-sensing protein Epac-2. However, the finding that GLP-1, when applied at a concentration of $1 \mathrm{pM}$, has almost no effect on intracellular cAMP levels, makes it unlikely that the low-affinity cAMP sensor Epac-2 contributes much to the stimulatory effect of picomolar concentrations of GLP-1.

of GLP-1 on insulin secretion, while not affecting that evoked by glucose alone. Further evidence for the involvement of PKC in the stimulatory effect of GLP-1 comes from the observations that its effect on $\beta$ cell electrical activity can be mimicked by the PKC activator PMA and the ability of GLP-1 to produce PKC-dependent phosphorylation of PKD1, previously identified as a regulator of insulin secretion (39). It seems possible that activation of PKC is downstream of $G_{a q}$-dependent activation of PLC. This is suggested by three pieces of evidence. First, GLP-1 binding to GLP-1R led to the activation of $G_{a q}$ in a yeast recombinant system expressing the mammalian $G$ protein (Figure 5). Second, pharmacologi-
The observation that GLP-1 did not increase intracellular cAMP (Figure 3, C and D) may seem in conflict with the finding that $60 \%$ of its stimulatory action on insulin secretion was inhibited by myr-PKI (Figure 3A). It could be argued that GLP-1 may produce an increase in cAMP too small to be detected by the assay we used here, but this explanation seems less likely, given that our measurements of PKA activity failed to detect any increase in its activity in response to GLP-1. Importantly, pretreatment of the cells with myr-PKI reduced basal PKA activity (Figure 3, E and F). Thus, it appears that PKA is tonically active in the $\beta$ cell and that such activity is required for the full secretory response. Indeed, 


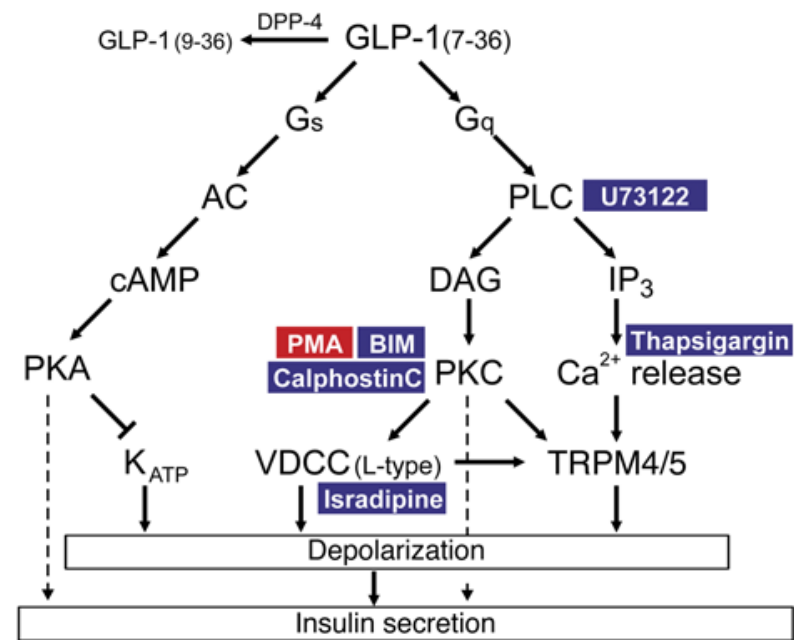

Figure 11. Schematic summarizing the effects of GLP-1 on signal transduction pathways relevant to the stimulation of insulin secretion. In addition to activating $G_{\alpha s}, G L P-1$ also leads to activation of $G_{\alpha q}$, leading to the activation of PLC and production of DAG, with resultant activation of PKC and elevation of $\left[\mathrm{Ca}^{2+}\right]_{\text {, }}$ by $\mathrm{IP}_{3}$-induced $\mathrm{Ca}^{2+}$ mobilization from thapsigargin-sensitive $\mathrm{Ca}^{2+}$ stores, which (together with the activation of PKC) results in activation of TRPM4 and TRPM5 channels, membrane depolarization, and initiation of action potential firing. GLP- 1 also stimulates $\mathrm{Ca}^{2+}$ entry via L-type $\mathrm{Ca}^{2+}$ channels, but this effect is relatively small and is not sufficient to explain the initiation of electrical activity. Additionally, GLP-1 closes $\mathrm{K}_{\text {ATP }}$ channels, accounting for the weak depolarization that persists at low extracellular $\mathrm{Na}^{+}$and in some $\mathrm{Trpm}^{-/-}$and $\mathrm{Trpm}^{-/-} \beta$ cells. Low concentrations of GLP also enhanced depolarization-evoked exocytosis, but this effect requires electrical activity/ $\mathrm{Ca}^{2+}$ entry to operate. This also explains why PKC inhibition leads to complete loss of insulin secretion stimulated by GLP-1. This is because, unless electrical activity is initiated, these distal effects will not operate. In the schematic, pharmacological activators and inhibitors are highlighted in red and blue, respectively. AC, adenylyl cyclase; VDCC, voltage-dependent $\mathrm{Ca}^{2+}$ channels.

not only the effect of GLP-1 was reduced by pretreatment with myr-PKI; there was also a tendency toward reduced insulin secretion to $6 \mathrm{mM}$ glucose.

GLP-1 stimulates electrical activity by a $\mathrm{Na}^{+}$-dependent mechanism. We found that GLP-1 increases the amplitude of the voltage-gated $\mathrm{Ca}^{2+}$ current. Pancreatic $\beta$ cells are equipped with several types of voltage-gated $\mathrm{Ca}^{2+}$ channel, but our measurements in both mouse and human $\beta$ cells suggest that GLP-1 selectively increases the L-type $\mathrm{Ca}^{2+}$ current, as no stimulation was detected in the presence of isradipine, a blocker of L-type $\mathrm{Ca}^{2+}$ channels. It is important to note, however, that the effect of GLP-1 on the $\mathrm{Ca}^{2+}$ current is fairly small and that GLP- 1 had no effect on the gating of the current. Thus, we argue that the contribution of the increased $\mathrm{Ca}^{2+}$ current to the stimulatory effect of GLP-1 on electrical activity and insulin secretion is marginal.

Our $\mathrm{Ca}^{2+}$ imaging experiments as well as membrane potential recordings suggest that an important component of the stimulatory action of GLP-1 is mediated by initiation of electrical activity (Figure 1D). Part of this effect may result from enhanced glucose-induced closure of the $\mathrm{K}_{\mathrm{ATP}}$ channels (as was previously reported, refs. 24, 26). Importantly, we observed no net reduction of the resting membrane conductance in response to GLP-1 and GLP-1 remained capable of stimulating electrical activity in the presence of a maximally inhibitory concentration of tolbutamide. Collectively, these observations suggest that closure of $\mathrm{K}_{\mathrm{ATP}}$ channels is not the sole mechanism by which GLP-1 stimulates $\beta$ cell electrical activity.

In both mouse and human $\beta$ cells, the ability of GLP-1 to produce membrane depolarization and initiate action potential firing was dependent on extracellular $\mathrm{Na}^{+}$. Thus, we confirm earlier reports that the action of GLP-1 involves a $\mathrm{Na}^{+}$-dependent mechanism (40, 41). However, the molecular identity of this $\mathrm{Na}^{+}$-permeable conductance was not conclusively established previously, and it is also unclear whether similar mechanisms operate in mouse and human $\beta$ cells. We can exclude involvement of voltage-gated $\mathrm{Na}^{+}$channels, because tetrodotoxin did not interfere with the stimulatory action of GLP-1 (data not shown). In voltage-clamp measurements, GLP-1 activated a small voltage-independent $\mathrm{Na}^{+}$-dependent inward current with an amplitude of only approximately $10 \mathrm{pA}$. However, because the input resistance of the $\beta$ cell is very high $(>1 G \Omega)$ in the presence of insulin-releasing glucose concentrations, even currents as small as this can exert a marked depolarizing effect on the membrane potential $(>10 \mathrm{mV})$ and trigger action potential firing. It is implicit from the small current activated by GLP-1 that it will not be able to initiate electrical activity and insulin secretion unless the $\mathrm{K}_{\mathrm{ATP}}$ channels are almost fully inhibited. This explains why the stimulatory effect of GLP- 1 is glucose dependent, with no or little stimulatory action at low glucose concentrations (Figure 1, B and C), and why GLP-1 loses its stimulatory effect on $\beta$ cell electrical activity in the presence of diazoxide. It is likely that our failure to detect much suppression of the resting $\mathrm{K}^{+}$conductance (principally reflecting $\mathrm{K}_{\text {ATP }}$ channel activity) is because the increase in membrane conductance resulting from the activation of a background $\mathrm{Na}^{+}$-dependent current obscures the reduction due to closure of the $\mathrm{K}_{\mathrm{ATP}}$ channels.

Our membrane potential and insulin secretion measurements in Trpm $4^{--}$and Trpm5 $5^{--} \beta$ cells and islets suggest that both TRPM4 and TRPM5 channels are crucial to the stimulatory effect of physiological concentrations of GLP-1. We attributed the stimulatory effect of GLP-1 on $\beta$ cell electrical activity, which remained after lowering $\left[\mathrm{Na}^{+}\right]_{\mathrm{o}}$, to membrane depolarization, resulting from $\mathrm{K}_{\text {ATP }}$ channel closure. A role of TRPM5 channels in the response to GLP1 is also consistent with the reported deterioration of glucose tolerance following oral glucose administration in Trpm $5 \mathrm{KO}$ mice (23).

TRPM4 and TRPM5 channels are $\mathrm{Ca}^{2+}$ activated (42). It is therefore of interest that application of GLP-1 produced an increase in $\left[\mathrm{Ca}^{2+}\right]_{\mathrm{i}}$ in hyperpolarized cells, suggesting it reflects mobilization from intracellular $\mathrm{Ca}^{2+}$ stores, that was sensitive to the SERCA inhibitor thapsigargin. It is also possible that the TRPM4 and TRPM5 channels are regulated by PKC in a $\mathrm{Ca}^{2+}$-independent way at the ambient submembrane $\left[\mathrm{Ca}^{2+}\right]_{\mathrm{i}}$. In this context, it is of interest that the PKC activator PMA mimics the effect of GLP-1 on electrical activity, and there is documented evidence for modulation of TRPM 4 and TRPM 5 by PKC $(43,44)$.

Coda. Information on the concentration dependence of the insulinotropic effect of GLP-1(7-36) has important physiological implications. The concentrations of GLP-1 customarily used in vitro (1-100 nM) (12-15) are several orders of magnitude higher than the physiological total plasma concentrations and even the portal concentration (>20 pM, ref. 45). In fact, most of the GLP-1 secreted 
by the intestinal L cells is rapidly degraded by DPP-4 and never reaches the pancreatic islets (46). If GLP-1 is only active at nanomolar concentrations (as suggested by in vitro assays of cAMP production; refs. 47, 48), then it is highly unlikely that circulating GLP-1 will stimulate insulin secretion. These considerations prompted the idea that the hormone instead acts by activation of vago-vagal reflexes (49). However, our findings that GLP-1 at concentrations as low as 1 pM evokes electrical activity in $\beta$ cells and results in a strong stimulation of insulin secretion in both mouse and human cells/islets (in agreement with previous findings in mouse insulinoma cells; refs. $50,51)$ argue that circulating levels of GLP-1(7-36) are adequate to account for the incretin effect. The concept that circulating levels mediate the effects of GLP-1 in vivo is also easily reconciled with the observation that the incretin effect remains intact in patients that have received a whole-pancreas transplant (52), i.e., when the normal innervation has been surgically severed.

\section{Methods}

Chemicals. GLP-1(7-36) amide and the GLP-1R antagonist exendin (9-39) were purchased from Bachem. The L-type calcium channel blocker isradipine was purchased from Alomone Labs. The membrane-permeable PKA inhibitors Rp-8-Br-cAMPS and myr-PKI were obtained from Biolog Life Science Institute and TOCRIS, respectively. The PKC inhibitors BIM and calphostin C were from Merck. Thapsigargin was purchased from TOCRIS. Tolbutamide, diazoxide, acetyl choline, PMA, U-73122 hydrate, and other compounds were obtained from Sigma-Aldrich.

Animals, mouse islet isolation, and cell culture. Most experiments were performed using islets and/or $\beta$ cells isolated from female NMRI mice (Charles River), fed a normal diet ad libitum.

Trpm $4^{-/}$and Trpm $5^{-/}$mice were generated as previously described $(35,53)$. Both mouse lines were backcrossed for 9 generations on the C57BL6/N background.

DKO mice for both $T p c 1$ and $T p c 2$ genes were derived from dihybrid crosses between $T p c 1^{\mathrm{T} 159}(54)$ and $T p c 2^{\mathrm{YHD} 437}$ (55) homozygote mutant animals. Lack of $T p c 1$ and $T p c 2$ expression was confirmed by RT-PCR. Age- and sex-matched C57BL6/N wild-type animals were used as controls.

Mice were kept in a conventional vivarium with a 12-hour-dark /12-hour-light cycle and ad libitum access to food and water and were killed by cervical dislocation.

Pancreatic islets were isolated by collagenase as previously reported (25). For preparation of single $\beta$ cells (electrophysiology), freshly isolated islets were incubated in enzyme-free Hank's medium (Invitrogen) and dissociated into cells/cell clusters by gentle trituration using a 1,000- $\mu$ l pipette. Dispersed cells were plated on plastic 35-mm tissue culture dishes (Sarstedt Inc.) and maintained in RPMI 1640 containing $10 \mathrm{mM}$ glucose (mouse) or $7.5 \mathrm{mM}$ glucose (human) supplemented with $10 \%$ calf serum, $100 \mathrm{U} / \mathrm{ml}$ penicillin, and $100 \mu \mathrm{g} / \mathrm{ml}$ streptomycin (Life Technologies Corporation). The cells were maintained in tissue culture for up to 36 hours before the electrophysiological experiments.

Human islets. Pancreatic islets were isolated in the Oxford Diabetes Research \& Wellness Foundation Human Islet Isolation Facility according to published protocols $(56,57)$. Single $\beta$ cells were prepared for electrophysiology essentially as described above for mouse cells.

Insulin measurements. Static and dynamic measurements of insulin release were performed as reported previously (25).
Electrophysiological recordings. All recordings were performed using an EPC-9 patch-clamp amplifier (HEKA Electronics) using the perforated patch whole-cell technique. Amphotericin B $(0.24 \mathrm{mg} / \mathrm{ml})$ was used to establish electrical contact with the cell interior as previously described (58). The extracellular solution for recordings of membrane potential contained $140 \mathrm{mM} \mathrm{NaCl}, 3.6 \mathrm{mM} \mathrm{KCl}, 1.5 \mathrm{mM} \mathrm{CaCl}_{2}$, $0.5 \mathrm{mM} \mathrm{MgSO}_{4}, 0.5 \mathrm{mM} \mathrm{NaH}_{2} \mathrm{PO}_{4}, 5 \mathrm{mM} \mathrm{NaHCO}_{3}, 10 \mathrm{mM}$ HEPES, and $6 \mathrm{mM}$ glucose ( $\mathrm{pH} 7.4$, with $\mathrm{NaOH})$. The pipette solution consisted of $128 \mathrm{mM} \mathrm{K}$-gluconate, $10 \mathrm{mM} \mathrm{NaCl}, 10 \mathrm{mM} \mathrm{KCl}, 1 \mathrm{mM} \mathrm{MgCl}_{2}$, and 5 mM HEPES ( $\mathrm{pH} 7.35$, with KOH). The extracellular solution for recordings of $\mathrm{Ca}^{2+}$ currents and capacitance contained $118 \mathrm{mM} \mathrm{NaCl}, 5.6 \mathrm{mM}$ $\mathrm{KCl}, 2.6 \mathrm{mM} \mathrm{CaCl}_{2}, 1.2 \mathrm{mM} \mathrm{MgCl}, 5 \mathrm{mM}$ HEPES, $20 \mathrm{mM}$ TEA-Cl, and $6 \mathrm{mM}$ glucose ( $\mathrm{pH} 7.4$, with $\mathrm{NaOH})$. The pipette solution consisted of $76 \mathrm{mM} \mathrm{Cs}_{2} \mathrm{SO}_{4}, 10 \mathrm{mM} \mathrm{NaCl}, 10 \mathrm{mM} \mathrm{KCl}, 1 \mathrm{mM} \mathrm{MgCl}_{2}$, and $5 \mathrm{mM}$ HEPES ( $\mathrm{pH} 7.35$, with $\mathrm{CsOH}$ ). When extracellular $\mathrm{Na}^{+}$was reduced to $20 \%$ of the normal concentration, it was substituted equimolarly by the nonpermeant cation $\mathrm{N}$-methyl-D-glucamine ${ }^{+}$.

For the measurement of exocytosis and $\mathrm{Ca}^{2+}$ currents, the cells were voltage clamped at $-70 \mathrm{mV}$, and voltage-dependent calcium channels were activated by $20-\mathrm{ms}$ depolarizations to $0 \mathrm{mV}$ applied at 1-minute intervals for measuring the effects of GLP-1 on the magnitude of the $\mathrm{Ca}^{2+}$ current.

Exocytosis was measured as increases in cell capacitance evoked by $500-\mathrm{ms}$ depolarizations from $-70 \mathrm{mV}$ to $0 \mathrm{mV}$ before and $10 \mathrm{~min}$ utes after applying GLP-1 using the Sine+DC technique (59).

Effects of GLP-1 on the whole-cell $\mathrm{K}_{\mathrm{ATP}}$ channel conductance were measured in the perforated patch mode by interrupting the membrane potential recordings (in the current-clamp mode) and switching the amplifier into the voltage-clamp mode. The whole-cell $\mathrm{K}_{\mathrm{ATP}}$ conductance was then measured by application of $\pm 10 \mathrm{mV}$ voltage excursion from a holding potential of $-70 \mathrm{mV}$. All electrophysiological measurements were made at $+32^{\circ} \mathrm{C}$. The identity of the $\beta$ cells was confirmed by immunohistochemistry as described previously $(60,61)$.

$\left[\mathrm{Ca}^{2+}\right]_{i}$ measurements. Confocal $\left[\mathrm{Ca}^{2+}\right]_{\mathrm{i}}$ imaging in intact islets was conducted essentially as described previously $(62)$. $\left[\mathrm{Ca}^{2+}\right]_{\mathrm{i}}$ imaging was also performed on isolated cells or small clusters following dissociation of the islets. In these experiments, cells were plated in glass-bottom dishes and maintained in tissue culture overnight in RPMI 1640 medium containing $10 \mathrm{mM}$ D-glucose. Prior to the experiments, the cells were washed twice in imaging buffer (63) containing $6 \mathrm{mM}$ D-glucose and then loaded with $2 \mu \mathrm{M}$ fluo-3AM in the same buffer for 45 minutes at $30^{\circ} \mathrm{C}$. After removal of the loading buffer, the cells were incubated for another 45 minutes in the absence of the indicator to allow complete de-esterification. In some experiments, $1 \mu \mathrm{M}$ thapsigargin was added during the de-esterification step after $25 \mathrm{~min}$ utes. The cells were superfused at a rate of approximately $1 \mathrm{ml} / \mathrm{min}$, and images were acquired on a Zeiss Axio Observer with $\times 40 / 1.2 \mathrm{~W}$ C-Apo Corr lens and illuminated by a Zeiss Colibri. 2 system at $488 \mathrm{~nm}$ with 15-ms exposure and 2 frames per second. Data are depicted as change in background corrected fluorescence relative to fluorescence at the beginning of the recordings.

cAMP measurements. The effect of GLP-1 on cAMP levels ([cAMP $]_{\mathrm{i}}$ ) in pancreatic islet cells was studied using a recombinant FRET sensor, Epac2-camps (27). Epac2-camps was delivered via an adenoviral infection (104 units per cell). The imaging experiments were performed 36 to 48 hours after infection using a Zeiss Axioskop 2FS microscope equipped with a $\times 40 / 1.3$ objective, Lambda DG- 4 exciter 
(Sutter Instruments), and Orca-R2 cooled CCD camera (Hamamatsu). The CFP fluorescence was excited at $436 \mathrm{~nm}$; the emitted light was collected at $485 \mathrm{~nm}$ and $535 \mathrm{~nm}$ using a Dual-View Beamsplitter (Photometrics). The images were acquired using open-source MicroManager software (developed at Ron Vale's lab, UCSF, San Francisco, California, USA), and fluorescence (F) was normalized to the initial fluorescence $\left(\mathrm{F}_{0}\right)$, after which the CFP/YFP ratio $(R)$ was calculated (using Image J) by dividing the intensity of fluorescence emitted at 485 $\mathrm{nm}(\mathrm{CFP})$ with that emitted at $535 \mathrm{~nm}$ (YFP). Data analysis and representation were performed with Igor Pro (Wavemetrics).

PKA activity measurements. Real-time changes in PKA activity were reported in pancreatic islet cells using recombinant FRET probe AKAR3 (28). Islets isolated from NMRI mice were dispersed into single cells and plated on glass coverslips. AKAR3 was delivered via an adenoviral infection $\left(10^{3}\right.$ units per cell). Imaging experiments were performed 36 hours after infection using a Zeiss Axioskop FS2 microscope equipped with a $\times 40 / 1.3$ objective (Carl Zeiss). The fluorescence was excited at $436 \mathrm{~nm}$; the emitted light was collected at 485 (CFP) and 515 (YFP) nm. The cells were kept at $33^{\circ} \mathrm{C}$ to $35^{\circ} \mathrm{C}$ and superfused continuously throughout the experiment. The images were acquired using Micro-Manager software and fluorescence $(F)$ normalized to the initial fluorescence $\left(F_{0}\right)$ using ImageJ. Data analysis and representation were performed with Igor Pro (Wavemetrics). AKAR3 was a gift from Jin Zhang, Department of Pharmacology and Molecular Sciences, The Johns Hopkins University School of Medicine, Baltimore, Maryland, USA.

DAG measurements. The effect of GLP-1 on $[\mathrm{DAG}]_{\mathrm{i}}$ in pancreatic islet cells was studied using a recombinant circularly permutated probe, Upward DAG (Montana Molecular). Islets isolated from NMRI mice were dispersed into a single-cell suspension as described above and plated on glass coverslips. Upward DAG was delivered via a BacMam infection $\left(10^{3}\right.$ units per cell), according to the manufacturer's guidelines. Imaging experiments were performed 48 hours after infection using a Zeiss AxioZoom.V16 zoom microscope equipped with a $\times 2.3 / 0.57$ objective (Carl Zeiss). The fluorescence was excited at $480 \mathrm{~nm}$, and the emitted light was collected at $515 \mathrm{~nm}$. The cells were kept at $33^{\circ} \mathrm{C}$ to $35^{\circ} \mathrm{C}$ and superfused continuously throughout the experiment. The images were acquired using Zen Blue software (Carl Zeiss) and normalized to the initial fluorescence and reported as $\mathrm{F} / \mathrm{F}_{0}$ using Image J. Data analysis and representation was performed with Igor Pro (Wavemetrics).

Determination of PKC-dependent activation of PKD1. Freshly isolated mouse islets were handpicked and maintained in RPMI supplemented with $6 \mathrm{mM}$ glucose, $10 \mathrm{mM}$ HEPES, and 0.1\% BSA for 5 hours prior to stimulation. Islets (150 per condition) were subsequently preincubated in RPMI with or without BIM for 60 minutes and stimulated for 10 minutes with the compounds indicated in the figure legends.

After incubation, the supernatants were discarded; islets were washed in ice-cold PBS once and lysed in RIPA buffer containing 20 mM Tris- $\mathrm{HCl}$ (pH 7.5), 150 mM NaCl, 1 mM EDTA, 1 mM EGTA, 1\% NP-40, 1\% sodium deoxycholate, $2.5 \mathrm{mM} \beta$-glycerophosphate, and 1 $\mathrm{mM} \mathrm{Na}_{3} \mathrm{VO}_{4}$; and supplemented with protease and phosphatase inhibitors (Life Sciences/Roche).

The lysates were subjected to SDS-PAGE, transferred to PVDF membrane (Bio-Rad), and probed with primary antibodies to phospho-PKD1 (Ser744/748 2054, Cell Signaling Technology) and total PKD1 (2052, Cell Signaling Technology), calnexin (208880, Calbiochem), and $\beta$ actin (ab49900, AbCam). HRP-conjugated secondary anti-mouse and anti-rabbit antibodies were from Dako. Blots were visualized using ECL detection reagent (Clarity Western ECL substrate, Bio-Rad) and exposure to X-ray film (Amersham Hyperfilm ECL, GE Healthcare). Each phospho-PKD blot was stripped and reprobed for total PKD1 to determine activation (phospho-PKD/total PKD intensity ratios). Data were expressed as mean fold change relative to no stimulation control in each experiment.

Yeast-based assay of GLP-1R activation of $G$ proteins. Yeast nitrogen base and yeast extract were purchased from Difco. Fluorescein-di- $\beta$-D-glucopyranoside (FDGlu) was purchased from Invitrogen. General yeast procedures were performed as described previously $(23,56)$. We have previously demonstrated the expression of human GLP-1R in dual-reporter chimeric $G \alpha_{q}$, and $G \alpha_{s}$ (MMY14 and MMY24) containing Saccharomyces cerevisiae strains (33). Receptor signaling was measured using the yeast growth assay. Cells were initially grown in SD-URA to establish a starter culture prior to overnight growth in SD-URA-HIS media at $30^{\circ} \mathrm{C}$ to remove basal activity. Yeast cells were then assayed using FDGlu-supplemented media in the presence of different concentrations of GLP-1 ligand (0.01 $\mathrm{nM}-10 \mu \mathrm{M})$. Fluorescence was measured on a TECAN Infinite M200 microplate reader (TECAN Ultra Evolution).

Statistics. Statistical analyses were performed using IBM SPSS statistics software. Unless otherwise indicated, data are presented as mean \pm SEM. Statistical significance was evaluated using the 2-tailed Student's $t$ test (single comparisons), ANOVA (multiple comparisons), or Friedman's test with Dunn-Bonferroni post-hoc (multiple comparisons on paired nonparametric data). Dunnett's test was used for posthoc analysis with ANOVA where data were compared with a single control or with multiple controls. A $P$ value of less than 0.05 was considered significant. All experiments on wild-type cells were performed on cells/islets pooled from multiple animals.

The concentration-response relationships (Figure 4) were analyzed using Prism 6.0e (Graphpad Software) using the 3-parameter logistic equation to obtain $\mathrm{EC}_{50}$ and the maximal effect $\left(\mathrm{E}_{\max }\right)$ values.

To derive the $\mathrm{Ca}^{2+}$ channel activation properties, the currents $(I)$ elicited by membrane depolarization to voltage $V$ were divided by the driving force $\left(V-E_{\mathrm{Ca}}\right.$, where $E_{\mathrm{Ca}}$ represents the reversal potential for the $\mathrm{Ca}^{2+}$ current determined experimentally for each experiment). The maximal current $\left(I_{\max }\right)$ and $E_{\mathrm{Ca}}$ were obtained by fitting each current-voltage $(I-V)$. The individual activation relation was fitted to the function

$\frac{I}{I_{\max }}=\frac{1}{1+e^{\left[\frac{V-V_{h}}{k}\right]}}$

(Equation 1)

where $V_{h}$ is the membrane potential at which the activation is halfmaximal and $k$ is the slope factor.

The dose-response relationship between GLP-1 and cytosolic cAMP (measured as $R$ ) was fitted with a Hill equation

$$
\frac{R-R_{\mathrm{o}}}{R_{\max }-R_{\mathrm{o}}}=\frac{1}{1+\left[\frac{E C_{50}}{[G L P-1]}\right]^{h}}
$$

(Equation 2) 
where $R$ is the CFP/YFP ratio of the Epac-2-camps sensor that was observed at the GLP-1 concentration of [GLP-1]; $R_{\max }$ is the CFP/YFP ratio at $100 \mathrm{nM} \mathrm{GLP}-1 ; R_{0}$ is the CFP/YFP ratio at $0 \mathrm{nM} \mathrm{GLP}-1 ; \mathrm{EC}_{50}$ is the concentration of GLP-1 that produces a half-maximal increase of $R$; and $h$ is the Hill (cooperativity) coefficient.

Study approval. All experiments on mouse $\beta$ cells and islets were conducted in accordance with the United Kingdom Animals (Scientific Procedures) Act (1986) and the University of Oxford ethical guidelines.

Breeding of Trpm 4 and Trpm 5 KO mice was approved by the ethical committee of Katholieke Universiteit Leuven.

Human pancreases were obtained with ethical approval of the NHS National Research Ethics Centre, Oxfordshire, United Kingdom (REC B) and clinical consent from heart-beating donors.

\section{Author contributions}

MS, RR, AIT, CYC, MVC, BH, KP, TR, NR, WRS, AS, EV, and CW researched data, contributed to the discussion, and reviewed/edited the manuscript. PRVJ supplied the human islets. AG and RV provided KO mouse models. VON and JG contributed to the cAMP measurements, and MZ contributed to the measurements of PKA activity. AG, MK, GL, RV, and KK contributed to the discussion. MS and PR planned the experiments and wrote the paper.

\section{Acknowledgments}

We thank David Wiggins for excellent technical assistance. This work was supported by the Medical Research Council, Diabetes UK (to R. Ramracheya ), Oxford Biomedical Research Centre (to A. Tarasov), the Wellcome Trust (Senior Investigator Awards to A. Galione and P. Rorsman), the Warwick Impact Fund (to C. Weston and G. Ladds), the Biotechnology and Biological Sciences Research Council (to G. Ladds), the Knut and Alice Wallenberg Foundation (to P. Rorsman), and the Swedish Research Council (to P. Rorsman). The initial stages of M. Shigeto's stay in Oxford were supported by a fellowship from Kawasaki Medical School.

Address correspondence to: Patrik Rorsman, Oxford Centre for Diabetes, Endocrinology and Metabolism, Churchill Hospital, Old Road, Oxford, OX37LE, United Kingdom. Phone: 44.1865.857348; E-mail:patrik.rorsman@drl.ox.ac.uk.
1. Danaei G, et al. National, regional, and global trends in fasting plasma glucose and diabetes prevalence since 1980: systematic analysis of health examination surveys and epidemiological studies with 370 country-years and 2.7 million participants. Lancet. 2011;378(9785):31-40.

2. Weir GC, Bonner-Weir S. Islet $\beta$ cell mass in diabetes and how it relates to function, birth, and death. Ann N Y Acad Sci. 2013;1281:92-105.

3. Deacon CF, Holst JJ. Dipeptidyl peptidase-4 inhibitors for the treatment of type 2 diabetes: comparison, efficacy and safety. Expert Opin Pharmacother. 2013;14(15):2047-2058.

4. Ussher JR, Drucker DJ. Cardiovascular actions of incretin-based therapies. Circ Res. 2014;114(11):1788-1803.

5. Balas B, et al. The dipeptidyl peptidase IV inhibitor vildagliptin suppresses endogenous glucose production and enhances islet function after single-dose administration in type 2 diabetic patients. J Clin Endocrinol Metab. 2007;92(4):1249-1255.

6. Ahrén B. DPP-4 inhibitors. Best Pract Res Clin Endocrinol Metab. 2007;21(4):517-533.

7. Imeryuz N, Yegen BC, Bozkurt A, Coskun T, Villanueva-Penacarrillo ML, Ulusoy NB. Glucagon-like peptide-1 inhibits gastric emptying via vagal afferent-mediated central mechanisms. Am J Physiol. 1997;273(4 pt 1):G920-G927.

8. Luque MA, et al. Glucagon-like peptide-1 (GLP-1) and glucose metabolism in human myocytes. JEndocrinol. 2002;173(3):465-473.

9. Lopez-Delgado MI, Morales M, VillanuevaPenacarrillo ML, Malaisse WJ, Valverde I. Effects of glucagon-like peptide 1 on the kinetics of glycogen synthase a in hepatocytes from normal and diabetic rats. Endocrinology. 1998;139(6):2811-2817.

10. Villanueva-Penacarrillo ML, Marquez L, Gonzalez N, Diaz-Miguel M, Valverde I. Effect of GLP-1 on lipid metabolism in human adipocytes. Horm Metab Res. 2001;33(2):73-77.
11. Valverde I, Merida E, Delgado E, Trapote MA, Villanueva-Penacarrillo ML. Presence and characterization of glucagon-like peptide-1(7-36) amide receptors in solubilized membranes of rat adipose tissue. Endocrinology. 1993;132(1):75-79.

12. Fridolf T, Ahren B. GLP-1(7-36) amide stimulates insulin secretion in rat islets: studies on the mode of action. Diabetes Res. 1991;16(4):185-191.

13. MacDonald PE, El-Kholy W, Riedel MJ, Salapatek AM, Light PE, Wheeler MB. The multiple actions of GLP-1 on the process of glucose-stimulated insulin secretion. Diabetes. 2002;51(suppl 3):S434-S442.

14. Gromada J, Brock B, Schmitz O, Rorsman P. Glucagon-like peptide-1: regulation of insulin secretion and therapeutic potential. Basic Clin Pharmacol Toxicol. 2004;95(6):252-262.

15. Doyle ME, Egan JM. Mechanisms of action of glucagon-like peptide 1 in the pancreas. Pharmacol Ther. 2007;113(3):546-593.

16. Henquin JC. Triggering and amplifying pathways of regulation of insulin secretion by glucose. Diabetes. 2000;49(11):1751-1760.

17. Goke R, et al. Exendin-4 is a high potency agonist and truncated exendin-(9-39)-amide an antagonist at the glucagon-like peptide 1-(7-36)-amide receptor of insulin-secreting beta-cells. J Biol Chem. 1993;268(26):19650-19655.

18. Knudsen LB, et al. Potent derivatives of glucagonlike peptide-1 with pharmacokinetic properties suitable for once daily administration. JMed Chem. 2000;43(9):1664-1669.

19. Holst JJ. The physiology of glucagon-like peptide 1 . Physiol Rev. 2007;87(4):1409-1439.

20. Bavec A, Hallbrink M, Langel U, Zorko M. Different role of intracellular loops of glucagon-like peptide-1 receptor in G-protein coupling. Regul Pept. 2003;111(1-3):137-144.

21. Hallbrink M, Holmqvist T, Olsson M, Ostenson CG, Efendic S, Langel U. Different domains in the third intracellular loop of the GLP-1 receptor are responsible for Galpha(s) and Galpha(i)/
Galpha(o) activation. Biochim Biophys Acta. 2001;1546(1):79-86.

22. Montrose-Rafizadeh C, et al. Pancreatic glucagon-like peptide-1 receptor couples to multiple $\mathrm{G}$ proteins and activates mitogen-activated protein kinase pathways in Chinese hamster ovary cells. Endocrinology. 1999;140(3):1132-1140.

23. Colsoul B, et al. Loss of high-frequency glucose-induced $\mathrm{Ca}^{2+}$ oscillations in pancreatic islets correlates with impaired glucose tolerance in Trpm5 $5^{-/}$mice. Proc Natl Acad Sci U S A. 2010;107(11):5208-5213.

24. Holz GGt, Kuhtreiber WM, Habener JF. Pancreatic beta-cells are rendered glucose-competent by the insulinotropic hormone glucagon-like peptide-1(7-37). Nature. 1993;361(6410):362-365.

25. Zhang $\mathrm{Q}$, et al. $\mathrm{Na}^{+}$current properties in islet $\alpha$ and $\beta$-cells reflect cell-specific Scn3a and Scn9a expression. JPhysiol. 2014;592(pt 21):4677-4696.

26. Gromada J, Ding WG, Barg S, Renstrom E, Rorsman P. Multisite regulation of insulin secretion by cAMP-increasing agonists: evidence that glucagon-like peptide 1 and glucagon act via distinct receptors. Pflugers Arch. 1997;434(5):515-524.

27. Nikolaev VO, Bunemann M, Hein L, Hannawacker A, Lohse MJ. Novel single chain cAMP sensors for receptor-induced signal propagation. J Biol Chem . 2004;279(36):37215-37218.

28. Allen MD, Zhang J. Subcellular dynamics of protein kinase A activity visualized by FRETbased reporters. Biochem Biophys Res Commun. 2006;348(2):716-721.

29. Suzuki Y, Zhang H, Saito N, Kojima I, Urano T, Mogami H. Glucagon-like peptide 1 activates protein kinase $\mathrm{C}$ through $\mathrm{Ca}^{2+}$-dependent activation of phospholipase $\mathrm{C}$ in insulin-secreting cells. J Biol Chem. 2006;281(39):28499-28507.

30. Rozengurt E. Protein kinase D signaling: multiple biological functions in health and disease. Physiology. 2011;26(1):23-33.

31. Gao ZY, Gilon P, Henquin JC. The role of protein kinase- $\mathrm{C}$ in signal transduction through vaso- 
pressin and acetylcholine receptors in pancreatic B-cells from normal mouse. Endocrinology. 1994;135(1):191-199.

32. Tewson P, Westenberg M, Zhao Y, Campbell RE, Quinn AM, Hughes TE. Simultaneous detection of $\mathrm{Ca}^{2+}$ and diacylglycerol signaling in living cells. PLoS One. 2012;7(8):e42791.

33. Weston C, Poyner D, Patel V, Dowell S, Ladds $\mathrm{G}$. Investigating $\mathrm{G}$ protein signalling bias at the glucagon-like peptide-1 receptor in yeast. $\mathrm{Br} J$ Pharmacol. 2014;171(15):3651-3665.

34. Gall D, Gromada J, Susa I, Rorsman P, Herchuelz A, Bokvist K. Significance of $\mathrm{Na} / \mathrm{Ca}$ exchange for $\mathrm{Ca}^{2+}$ buffering and electrical activity in mouse pancreatic $\beta$-cells. Biophys J. 1999;76(4):2018-2028.

35. Rorsman P, Eliasson L, Kanno T, Zhang Q, Gopel S. Electrophysiology of pancreatic $\beta$-cells in intact mouse islets of Langerhans. Prog Biophys Mol Biol. 2011;107(2):224-235.

36. Low JT, et al. Glucose principally regulates insulin secretion in mouse islets by controlling the numbers of granule fusion events per cell. Diabetologia. 2013;56(12):2629-2637.

37. Kim BJ, et al. Generation of nicotinic acid adenine dinucleotide phosphate and cyclic ADP-ribose by glucagon-like peptide- 1 evokes $\mathrm{Ca}^{2+}$ signal that is essential for insulin secretion in mouse pancreatic islets. Diabetes. 2008;57(4):868-878.

38. Arredouani A, Evans AM, Ma J, Parrington J, Zhu $\mathrm{MX}$, Galione A. An emerging role for NAADPmediated $\mathrm{Ca}^{2+}$ signaling in the pancreatic $\beta$-cell. Islets. 2010;2(5):323-330.

39. Sumara G, et al. Regulation of PKD by the MAPK p38 $\Delta$ in insulin secretion and glucose homeostasis. Cell. 2009;136(2):235-248.

40. Fridolf T, Ahren B. GLP-1(7-36)amidestimulated insulin secretion in rat islets is sodium-dependent. Biochem Biophys Res Commun. 1991;179(1):701-706.

41. Kato M, Ma HT, Tatemoto K. GLP-1 depolarizes the rat pancreatic beta cell in a $\mathrm{Na}(+)$-dependent manner. Regul Pept. 1996;62(1):23-27.

42. Nilius B, et al. Voltage dependence of the $\mathrm{Ca}^{2+}$-activated cation channel TRPM4. J Biol Chem. 2003;278(33):30813-30820.
43. Vennekens R, Nilius B. Insights into TRPM4 function, regulation and physiological role. Handb Exp Pharmacol. 2007;(179):269-285.

44. Liman ER. TRPM5 and taste transduction. Handb Exp Pharmacol. 2007;(179):287-298.

45. Toft-Nielsen MB, et al. Determinants of the impaired secretion of glucagon-like peptide- 1 in type 2 diabetic patients. JClin Endocrinol Metab. 2001;86(8):3717-3723.

46. Hansen L, Deacon CF, Orskov C, Holst JJ. Glucagon-like peptide-1-(7-36)amide is transformed to glucagon-like peptide-1-(9-36)amide by dipeptidyl peptidase IV in the capillaries supplying the $\mathrm{L}$ cells of the porcine intestine. Endocrinology. 1999;140(11):5356-5363.

47. Gefel D, Hendrick GK, Mojsov S, Habener J, Weir GC. Glucagon-like peptide-I analogs: effects on insulin secretion and adenosine 3',5'-monophosphate formation. Endocrinology. 1990;126(4):2164-2168.

48. Green BD, Gault VA, Flatt PR, Harriott P, Greer B, O'Harte FP. Comparative effects of GLP-1 and GIP on cAMP production, insulin secretion, and in vivo antidiabetic actions following substitution of Ala8/Ala2 with 2-aminobutyric acid. Arch Biochem Biophys. 2004;428(2):136-143.

49. Holst JJ, Deacon CF. Glucagon-like peptide-1 mediates the therapeutic actions of DPP-IV inhibitors. Diabetologia. 2005;48(4):612-615.

50. Gromada J, et al. Glucagon-like peptide I increases cytoplasmic calcium in insulinsecreting beta TC3-cells by enhancement of intracellular calcium mobilization. Diabetes. 1995;44(7):767-774.

51. Shigeto M, Katsura M, Matsuda M, Ohkuma S, Kaku K. Low, but physiological, concentration of GLP-1 stimulates insulin secretion independent of the cAMP-dependent protein kinase pathway. JPharmacol Sci. 2008;108(3):274-279.

52. Rickels MR, Mueller R, Markmann JF, Naji A Effect of glucagon-like peptide- 1 on $\beta$ - and $\alpha$-cell function in isolated islet and whole pancreas transplant recipients. JClin Endocrinol Metab. 2009;94(1):181-189.

53. Vennekens R, et al. Increased IgE-dependent mast cell activation and anaphylactic responses in mice lacking the calcium-activated nonselective cation channel TRPM4. Nat Immunol. 2007;8(3):312-320

54. Ruas M, et al. TPC1 has two variant isoforms, and their removal has different effects on endo-lysosomal functions compared to loss of TPC2. Mol Cell Biol. 2014;34(21):3981-3992.

55. Calcraft PJ, et al. NAADP mobilizes calcium from acidic organelles through two-pore channels. Nature. 2009;459(7246):596-600.

56. Lake SP, et al. Large-scale purification of human islets utilizing discontinuous albumin gradient on IBM 2991 cell separator. Diabetes. 1989;38(suppl 1):143-145.

57. Ricordi C, Lacy PE, Finke EH, Olack BJ, Scharp DW. Automated method for isolation of human pancreatic islets. Diabetes. 1988;37(4):413-420.

58. Ammala C, Ashcroft FM, Rorsman P. Calcium-independent potentiation of insulin release by cyclic AMP in single $\beta$-cells. Nature. 1993;363(6427):356-358

59. Ammala C, Eliasson L, Bokvist K, Larsson O, Ashcroft FM, Rorsman P. Exocytosis elicited by action potentials and voltage-clamp calcium currents in individual mouse pancreatic B-cells. J Physiol. 1993;472:665-688.

60. Braun M, et al. Voltage-gated ion channels in human pancreatic $\beta$-cells: electrophysiological characterization and role in insulin secretion. Diabetes. 2008;57(6):1618-1628.

61. Gopel SO, et al. Activation of $\mathrm{Ca}(2+)$-dependent $\mathrm{K}(+)$ channels contributes to rhythmic firing of action potentials in mouse pancreatic $\beta$ cells. JGen Physiol. 1999;114(6):759-770.

62. Girard CA, et al. Expression of an activating mutation in the gene encoding the KATP channel subunit Kir6.2 in mouse pancreatic $\beta$ cells recapitulates neonatal diabetes. JClin Invest. 2009;119(1):80-90.

63. Reinbothe TM, Safi F, Axelsson AS, Mollet IG, Rosengren AH. Optogenetic control of insulin secretion in intact pancreatic islets with $\beta$-cell-specific expression of Channelrhodopsin-2. Islets. 2014;6(1):e28095. 